\title{
RECENT REgulatory AND LEgISLATIVE DEVELOPMENTS OF INTEREST TO OIL AND GAS LAWYERS
}

\author{
LUIG A. CUSANO AND DAVID M. WOOD
}

In this article the authors highlight regulatory and legislative developments during the period of May 2000 through April 2001 that are of particular interest to oil and gas lawyers. Decisions of the National Energy Board and the Alberta Energy and Utilities Board are the primary focus for regulatory developments. Key policy developments, guidelines and directives of the AEUB, the CanadianNewfoundland Offshore Petroleum Board and the Canada-Nova Scotia Offshore Petroleum Board are also examined.

With respect to legislative developments, particular emphasis is placed on Alberta and federal legislative developments, although notable developments in other jurisdictions are also highlighted.
Dans cet article, les auteurs soulignent l'élaboration des règlements et des lois qui a eu lieu entre mai 2000 et avril 2001 ayant un intérêt particulier pour les avocats qui travaillent dans l'industrie pétrolière et gazière. L'élaboration des règlements s'articule surtout autour des décisions de l'Office national de l'énergie et du Alberta Energy and Utilities Board (AEUB). L'élaboration des grandes politiques, des lignes directrices et des directives du $A E U B$, du Canadian-Newfoundland Offshore Petroleum Board et du Canada-Nova Scotia Offshore Petroleum Board y est aussi examinée.

En ce qui concerne l'élaboration des lois, l'emphase est mise sur celles de l'Alberta et du gouvernement fédéral, bien que des développements notables dans d'autres juridictions $y$ sont aussi soulignés.

\section{TABLE OF CONTENTS}

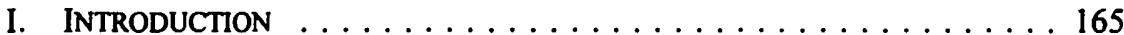

II. REGULATORY DEVELOPMENTS $\ldots \ldots \ldots \ldots \ldots \ldots \ldots \ldots \ldots$

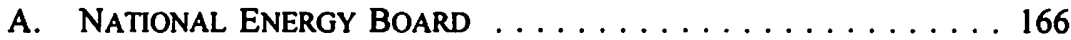

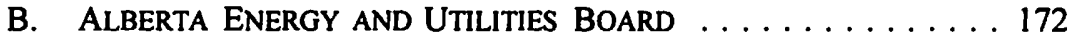

III. LEGISLATIVE DEVELOPMENTS $\ldots \ldots \ldots \ldots \ldots \ldots \ldots \ldots \ldots$

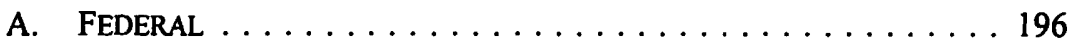

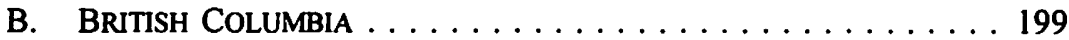

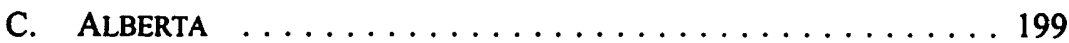

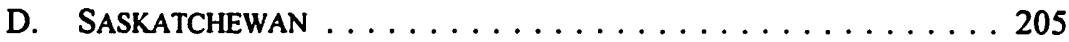

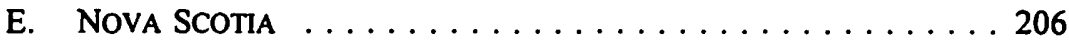

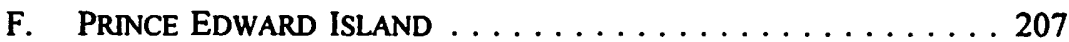

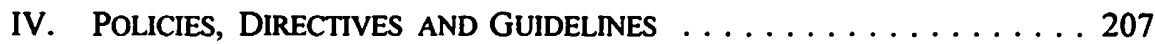

A. CANADA-NEWfOUNDLAND OfFSHORE PETROLEUM BOARD ("CNOPB") AND CANADA-NOVA SCOTIA

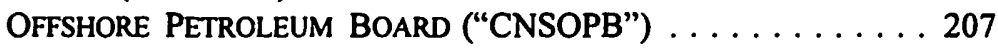

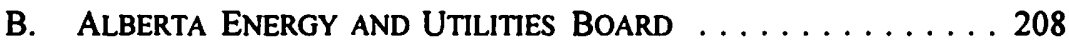

\section{INTRODUCTION}

The purpose of this article is to highlight regulatory and legislative developments during the period between May 2000 and April 2001 that are of particular interest to oil and gas lawyers. With respect to regulatory developments, the article primarily examines

Donahue Emst \& Young, Calgary, Alberta. The authors gratefully acknowledge the invaluable assistance of Joan Bilsland and Sandra St. Cyr. 
decisions of the National Energy Board ("NEB")' and the Alberta Energy and Utilities Board ("AEUB"). ${ }^{2}$ Additionally, the article details certain key policy developments, guidelines, and directives of the AEUB, the Canada-Newfoundland Offshore Petroleum Board ("CNOPB") and the Canada-Nova Scotia Offshore Petroleum Board ("CNSOPB").

With respect to legislative developments, particular emphasis is placed on Alberta and federal legislative developments, although notable developments in other jurisdictions are also highlighted.

\section{REgulatory DEVELOPMENTS}

\section{A. NATIONAL ENERGY BOARD}

The period between May 2000 and April 2001 appears to have been relatively quiet for the NEB in terms of hearings and decisions. The NEB continued to be confronted with the issue of jurisdiction and dealt with the extent and nature of the statutory common carrier obligations and the accuracy of cost estimates. The NEB has also reaffirmed its position on several fundamental legal principles, including the use of prior decisions as precedent, the burden of proof and the need for interveners to call evidence.

\section{Westcoast ENERGY INC.: PURCHASE AND OPERATION OF FACILITIES ${ }^{3}$}

This was an application by Westcoast Energy Inc. ("Westcoast") to purchase and operate approximately 67.6 kilometres of 12 -inch pipeline and associated facilities in the Maxhamish area of northeast British Columbia from AEC Oil \& Gas Co. Ltd. ("AEC"). Westcoast also sought a certificate of public convenience and necessity to operate the Maxhamish pipeline as a sour raw gas transmission pipeline.

The British Columbia Ministry of Energy and Mines ("Ministry") argued in final argument that it was concerned that, through a simple change in ownership, a provincially approved and regulated pipeline could fall under federal regulation. The Ministry argued that the mere change in ownership of the Maxhamish pipeline could not alter the fact that the pipeline remained fundamentally a local undertaking that should be provincially regulated; that there was little evidence on the record to show that the pipeline would be functionally integrated into Westcoast's system; that the purpose and function of the Maxhamish pipeline was different from Westcoast's interprovincial system; and that the purchase by Westcoast of the Maxhamish pipeline would not cause it to lose its distinctive local character. The Ministry relied particularly on the dissenting opinion of McLachlin J. (as she then was) in Westcoast Energy Inc. v. Canada (N.E.B.). ${ }^{4}$

NEB decisions can be obtained from the NEB's web site, online: <http://www.neb-one.gc. ca/regupd/decision/index_e.htm>.

Access to AEUB decisions, guidelines, directives, and other releases to the industry can be obtained from the AEUB's web site, online: <http://www.eub.gov.ab.ca/CyberDOCS30/Libraries/Default_ Library/Common/frameset.asp?>.

(March 2001), GHW-3-2000 (N.E.B.).

[1998] I S.C.R. 322 [hereinafter Westcoast]. 
In reply, Westcoast argued that the Ministry's submission on jurisdiction was patently wrong. Westcoast relied on the majority opinion of the Supreme Court in Westcoast and particularly on the Court's affirmation that there was exclusive federal jurisdiction over the entire Westcoast system, including expansion facilities. Westcoast argued that if the purchase and operation of the Maxhamish pipeline were approved, it would become fully integrated in Westcoast's operations and subject to common control, direction and management with the rest of the Westcoast system.

The NEB ruled that the Supreme Court of Canada had made it clear in Westcoast that the Westcoast system fell under federal jurisdiction. The NEB pointed out that this included gathering and processing facilities operated by Westcoast as well as the mainline. The NEB noted that the evidence before it was that the Maxhamish pipeline would be functionally integrated into the Westcoast system and would be subject to common management, operation and control. The NEB stated that it was not persuaded by the Ministry's argument that the pipeline would remain fundamentally provincial in character. The NEB noted that the Ministry's submission relied solely on the dissent in Westcoast and did not address the fact that the majority had clearly ruled that the entire Westcoast system fell under federal jurisdiction.

\section{MARTIMES \& NORTHEAST PIPELINE MANAGEMENT LTD.: TOLlS ${ }^{5}$}

In GH-696, the NEB approved a pipeline to transport Sable Island natural gas from Goldboro, Nova Scotia, through the provinces of Nova Scotia and New Brunswick to a point on the international boundary between Canada and the United States near St. Stephen, New Brunswick. This pipeline is known as the Maritimes \& Northeast Pipeline Management Ltd.'s ("M\&NP") mainline. On September 17, 1999, the NEB approved M\&NP's gas transportation tariff. In granting the approval, the NEB stated that parties with unresolved concerns regarding the tariff could raise them with the NEB at any time. The NEB also directed M\&NP to file an application for final tolls by February 28, 2000. On that date, M\&NP applied to the NEB for final tolls effective December 1, 1999.

The application covered the ten-month test period from December 1, 1999, to September 30, 2000. The initial application included the costs and volumes associated with the M\&NP mainline and the Point Tupper Lateral. However, M\&NP subsequently amended its application to remove the Point Tupper Lateral costs and volumes when it became clear that the lateral would not be in service during the test period.

The NEB agreed with M\&NP that the NEB had to base its decision on the prudence of the costs applied for and not on the accuracy of the previous cost estimates. However, the NEB ruled that while recognizing the cost estimates are subject to amendment, it was concerned that applicants should exercise care and attention in developing such estimates. The NEB noted that it, and interested parties, rely on such estimates to assess the economics of a project as well as the extent of support for and, in the case of the NEB, its approval of a project. 
In the case of the M\&NP mainline there were significant cost overruns. The NEB considered the cost overruns, the validity and reliability of construction estimates, the degree and competence of project supervision, contractor selection, the propriety of decisions to begin construction on a certain date, the attempt to complete by that date, and M\&NP's attempts to control expenditures. The NEB noted, M\&NP had told the NEB that its original cost estimate was of "bid quality" and was carefully determined. However, the NEB stated that it believed there were significant weaknesses in the initial costing of certain items. For example, the NEB strongly questioned the initial cost estimate of $\$ 513,000$ for the handling of acid rock. The actual cost of handling acid rock was $\$ 7.6$ million. The NEB further stated that it considered the variances from estimates to be even more significant when it took into account the fact that these cost estimates initially incorporated a contingency allowance of approximately $\$ 50$ million.

The NEB identified a number of what it termed "questionable management practices and decisions" but ultimately determined, based on all of the evidence before it, that M\&NP's management practices and decisions met the standard of prudence applied by the NEB in allowing costs for the purpose of determining just and reasonable tolls.

The NEB did, however, disallow a number of relatively significant costs. The NEB held that a consulting fee claimed by M\&NP did not result in any additional care or supervision over the level of cost control than was reasonable to expect otherwise. Additionally, the NEB noted the formula for calculating the consulting fee specifically provided for the consulting fee to be lost if cost overruns exceeded 10 percent. Considering the magnitude of the cost overrun, the NEB stated that it would not be reasonable to allow the consulting fee to be part of the rate base, and it disallowed the entire \$6.6 million consulting fee.

M\&NP had also claimed a fee of 230 percent of salaries paid to the project manager. The NEB noted that no detailed evidence had been filed to support the fair market value of the services rendered in respect of this fee. Consequently, the NEB held it was unable to determine that the services rendered by the project manager were provided at fair market value. In any event, the NEB stated it was of the view that, in the circumstances of this case, the profit paid to affiliates was not appropriate for inclusion in tolls, and it disallowed the portion of the costs that was paid as profit.

Finally, with respect to the claimed annual management fee the NEB stated that it did not accept that the fee was a legitimate cost of providing pipeline service. It held that, under the cost of service regulation, costs were recoverable through tolls if they are incurred to provide service to customers, with the inclusion of a reasonable amount for return. The NEB remarked that any amount realized in addition to the allowed return is for the account of the utility, as would be any additional expenses associated with earning the extra return. The NEB ruled that the annual management fee should not be included in tolls. The NEB added that it was concerned M\&NP believed it needed to pay a fee to ensure the pipeline was operated in an efficient and effective manner.

Ibid. at 22. 
The NEB also took the opportunity to address a number of legal issues raised during the hearing, including burden of proof, evidence and use of past NEB decisions.

A number of parties raised the question of what burden of proof an applicant had to meet. The NEB harkened back to its reasons for decision in RH-1-92 and reaffirmed its view, as expressed in that decision.' Briefly, the NEB stated that the process by which an applicant undertakes to discharge its ultimate burden of proof begins with the filing of an application, which must contain evidence amounting to a prima facie case in support of the requested relief. The NEB pointed out that this evidence is augmented by responses to information requests, written evidence and cross-examination. The NEB noted that, depending upon the strengths and weaknesses of the applicant's prima facie case, the onus of proof may shift to interveners during the course of the hearing to refute the applicant's case. The NEB hastened to add that notwithstanding this shift the ultimate burden of proof always remained with the applicant. Thus it was ultimately up to the applicant to satisfy the NEB, on a balance of probabilities, that the relief sought in its application should be granted.

The NEB pointed out that whether an intervener chooses to file evidence to support a view is a tactical decision for the intervener to make. The NEB further noted, in cases where an applicant's case is particularly strong, the decision not to adduce evidence would be made at an intervener's risk; that is, less weight might be attributed to the contentions of the intervener than would otherwise have been the case if the intervener had offered evidence, which could have been tested at a hearing.

The NEB also reiterated its ruling in an earlier case ${ }^{8}$ in which the NEB stated that, as a matter of practice, it expected to hear alternative proposals and new approaches offered by parties through evidence followed by argument based on that evidence. In the earlier ruling the NEB had also expressed the view that it expected parties to advance substantive positions by way of fact and agreement, not argument alone.

The NEB pointed out that facts can be elicited not only by direct evidence, but also through cross-examination or by other means, without having to produce direct evidence. The NEB noted that when conducting cross-examination it would allow questions soliciting facts from a witness who has personal knowledge of those facts, subject to any objections on established grounds, including relevance, privilege or confidentiality.

Finally, some parties raised an issue with respect to the use of past NEB decisions as precedents. The NEB stated that as an administrative tribunal it strove to achieve continuity, consistency and a degree of predictability. The NEB pointed out that if a principle from a past decision could be applied to a case before the NEB, it may choose to rely on that principle in deciding the case before it. However, the NEB noted that it would not decide the case before it solely on the basis of the principles contained in its earlier decisions because this would inappropriately confine the NEB's exercise of its

Ibid. at 45.

TransCanada Pipelines Limited Interruptible Transportation and Short-Term Firm Transportation Tariff Amendments (April 2000), RH-1-99 (N.E.B.) at 28. 
statutory discretion. The NEB also stated a strict adherence to past decisions could constrain its ability to adapt to new situations or changes in policy in order to fulfill its mandate. Accordingly, the NEB reaffirmed that it is not strictly bound by the principle of stare decisis, but the NEB may, in specific cases, decide to consider and apply principles articulated in its earlier decisions.

\section{TRANS-NORTHERN PIPELINES INC.: SUSPENSION OF SERVICE ${ }^{9}$}

In this case the operator of an oil pipeline applied to the NEB to be relieved from its statutory common carrier obligations. Trans-Northern Pipelines Inc. ("TNPI") owns and operates a pipeline system extending from Nanticoke, Ontario to Montreal, Quebec. The system includes five lateral pipelines, including one known as the Don Valley Lateral. On February 15, 2000, TNPI advised its shippers and the NEB of plans to suspend deliveries on the Don Valley Lateral, effective January 1, 2001. TNPI stated that this suspension was required because of the steady decline in volumes, which had resulted in a situation where the cost of service to operate the Don Valley Lateral was significantly greater than the revenue generated by the lateral. A shipper expressed concern about the suspension of service, but TNPI argued that this shipper was a minor shipper with access to truck and marine transportation alternatives.

Operators of oil pipelines, as defined in the National Energy Board Act, ${ }^{10}$ are subject to the statutory common carrier obligation set out in s. 71. TNPI acknowledged that it was a common carrier and that $\mathrm{s}$. 71 imposed upon it the statutory obligation to provide service. However, TNPI argued that those obligations had to be interpreted as being relative rather than absolute and ought to be determined using a standard of reasonableness.

The NEB held the statutory provision imposing common carrier obligations has to be considered within the circumstances of each case. The NEB reiterated its ruling from an earlier decision that statutory service obligations imposed by law on regulated undertakings were relative rather than absolute." One of the issues raised by the shipper was the extent to which the concept of "undue burden" applied to the circumstances.

The concept of undue burden is expressly set out in s. 71(3) of the National Energy Board Act in the context of the power of the NEB to require a company operating a pipeline to construct or expand facilities. However, as the NEB pointed out, there is no reference to the concept of "undue burden" in either s. 7I(1) (which requires a company operating a pipeline to receive, transport, and deliver all oil offered for transmission subject to any exemptions, conditions or regulations as the NEB may prescribe) or s. 71(2) (which extends a common carrier type of obligation to companies operating pipelines for the transmission of commodities other than oil). 
The NEB held that with respect to s. 71(1), which was at issue in the case before the NEB, Parliament could not have intended that the criteria in s. 71(3) would be applied in the same manner because the two subsections had different purposes and different wording. Rather, the NEB concluded, the burden on a company would be one relevant factor to be considered and balanced with any other existing public interest factors in determining the extent of its obligations under s. 71(1).

In light of the significant disparity between the cost of service and the revenues generated by the Don Valley Lateral, the NEB concluded continued operation of the lateral was uneconomic; maintaining the operation of the Lateral would require substantial cross-subsidization from other shippers, which would be unreasonable and contrary to the public interest. The NEB considered opposing arguments from TNPI and the shipper with respect to whether the NEB should consider the economic viability of the Don Valley Lateral on its own or as part of the entire TNPI system. The NEB ruled that the Don Valley Lateral was a distinct entity to which definite costs could be assigned within the TNPI system and that the TNPI system could clearly operate with or without the Don Valley Lateral. Accordingly, the NEB ruled that consideration of the economic viability of the Don Valley Lateral was required.

The shipper also argued that the NEB had to consider the impact that a suspension of service of the Don Valley Lateral would have on the shipper. The NEB ruled that the effect of a proposed suspension of service on the viability of any individual shipper's business was a factor that might be weighed in relation to the overall public interest when applying a test of reasonableness. However, the NEB ruled that in the case before it, little weight could be attributed to this factor because there was no persuasive evidence to suggest that such an outcome would have any appreciable negative impact on the broader public interest. After weighing all of the evidence, the NEB ruled it would be in the public interest to grant TNPI relief from its obligations pursuant to s. 71(1) of the National Energy Board Act and allowed TNPI to suspend service on the Don Valley Lateral.

\section{Proposed TransCanada Pipelines limited ("TCPL”) AMAlgamation WITH NOVA GaS TRANSMISSION LTD. ("NGTL")}

TCPL has announced a proposal to amalgamate with NGTL under provincial legislation. Perhaps foreshadowing a jurisdictional dispute, the NEB requested TCPL (which is regulated by the NEB) to explain in writing why the proposed amalgamation should not require NEB approval. The Daily Oil Bulletin reported that the NEB sent a letter to the Senior Vice-President of Regulatory Strategy at TCPL setting out a dozen questions, including whether the company had obtained an external opinion as to whether the amalgamation could proceed without NEB approval. ${ }^{12}$ The NEB also ordered TCPL to send to interested parties its original correspondence to the NEB, the NEB letter seeking clarification and TCPL's response. 2001). 
In a letter dated April 6 to the NEB, TCPL stated that it planned to continue TCPL under the Alberta Business Corporations $\mathrm{Act}^{13}$ as a provincially-incorporated entity. TCPL also stated that it intended to amalgamate TCPL and NGTL by way of a vertical short-form amalgamation. TCPL argued that s. 74(1) of the National Energy Board Act, which requires a company regulated by the NEB to seek leave of the NEB to enter into an agreement for amalgamation with any other company, did not apply to vertical amalgamations between related companies.

\section{B. ALBERTA ENERGY AND UTILITIES BOARD}

A number of themes emerge from the decisions of the AEUB. The AEUB continues to be concerned about the adequacy and sufficiency of the public consultation undertaken by facilities applicants. The AEUB has identified public consultation programs that get off to an inauspicious start as a factor contributing to mistrust between the public and industry members. The AEUB has given some guidance regarding the appropriate models to be used for modelling plume dispersion and has also explained how it treats commitments made by an applicant outside the hearing room. The AEUB also attached conditions to some approvals that, while perhaps not strictly required, appear to be designed with the goal of reassuring the public.

The AEUB continued to encourage applicants to address regional concerns and cumulative effects and to participate in regional or area groups. The AEUB expressed concern about the breadth of information being covered by confidentiality agreements entered into by parties that participate in mediations or other forms of alternative dispute resolution (or "appropriate dispute resolution," to use the AEUB's nomenclature).

The AEUB examined the "first well" in a new pool policy and concluded that there was sufficient ambiguity to warrant a Board and industry review. The AEUB also shut in a large number of gas wells in order to protect certain crude bitumen reserves.

\section{RANGER OIL LIMTED: COLD LAKE OILSANDS AREA PRIMARY RECOVERY SCHEME ${ }^{14}$}

Ranger Oil Limited ("Ranger") applied to the AEUB for an amendment to an existing primary recovery scheme approval for the recovery of crude bitumen ${ }^{15}$ in the Cold Lake Oilsands area. Ranger applied to amend the existing approval by adding a number of areas and reducing the drilling spacing unit to four hectares in both the proposed amendment area and the existing approval area. According to Ranger, because of high bitumen viscosity and the relatively low mobility of the bitumen in the oilsands, smaller spacing between wells was required to optimize recovery of the bitumen in place. Ranger stated that the projected recovery factor was between 5 percent and 10 percent of bitumen in

$13 \quad$ S.A. 1981, c. B-15.

14 (April 2000), 2000-23 (A.E.U.B.).

is Crude bitumen is a naturally occurring viscous mixture, mainly of hydrocarbons heavier than pentane, that may contain sulphur compounds and that, in its naturally occurring viscous state, will not flow to a well. 
place, and that approval of the four-hectare spacing would give it the required flexibility to maximize recovery, depending on geological conditions. Some of the interveners expressed concern that a recovery of 10 percent of bitumen in place at the risk of destruction of aquifers was unacceptable and that recovery should not be allowed to take place until technology improved to allow increased recoveries of at least 40 percent.

The AEUB noted that Ranger had not provided "definitive evidence" to support the need for four-hectare spacing for the entire project area but noted that the majority of the project area would likely be developed on eight-hectare spacing. The AEUB recognized that the geology of the oilsands deposits in the area was such that four-hectare spacing would be required to maximize recovery in some areas. The AEUB also noted that the majority of the primary recovery projects in the Cold Lake oilsands area were being developed on four-hectare spacing. Accordingly, the AEUB approved four-hectare spacing for the entire project area in order to provide Ranger with operational flexibility and to ensure maximization of the bitumen recovery.

Ranger did not propose to construct more than four pads per quarter section in accordance with existing AEUB guidelines. Ranger recognized that there would be increased truck traffic in the area and estimated that truck-trips per year would be in the order of 60,000 to 70,000 . A number of interveners argued that the significant number of low bitumen producers on Ranger's leases demonstrated Ranger was not capable of producing large amounts of bitumen and, therefore, was unable to justify its proposed development. They also stated that up to ten acres per quarter section of viable agricultural land would become unproductive over the application's area. Several landowners argued that no well sites should be allowed to be developed in the middle of a productive field and that Ranger should be directed to locate the pad sites in corners of the quarter sections or in locations least intrusive to the operations of the landowners. A number of landowners also argued that all existing well sites producing less than $25 \mathrm{~m}^{3}$ must be abandoned and reclaimed within one operating year of reaching this level. The landowners argued that Ranger's estimate of trucking movement was grossly understated and would likely be 100,000 truck-trips per year.

The AEUB noted Ranger's commitment to limiting the number of pads per quarter section to no more than four and encouraged Ranger, through consultation with landowners, to select pad sites and access road locations that would minimize impacts on agriculture operations and residents to the extent possible. The AEUB also approved Ranger's plans to set surface casings below the lowest possible usable water zone and to cement all casing strings to surface. Consequently, the AEUB stated that groundwater contamination would not likely occur from well production operations.

A number of landowners urged the Board to direct Ranger to electrify all of its well sites. Ranger argued that this was not economically feasible. The AEUB recognized the many factors Ranger had to consider when reviewing the feasibility of electrifying its wells. The AEUB stated that it nevertheless expected Ranger to include the need to bring its operations into compliance with Interim Directive 99-08: Noise Control Directive. ${ }^{16}$ 
The AEUB expressed concern about the interveners' evidence respecting wells at which the surface abandonment had not been completed, especially where there was some evidence that the subsurface abandonment plugs were leaking. The AEUB also expressed concern that Ranger may not have taken adequate precautions to fence these sites to protect the public. The AEUB stated that it expected Ranger to complete the subsurface abandonment of these sites and any other sites not brought to the AEUB's attention within a stipulated time frame. The AEUB added that it also expected Ranger to initiate internal procedures to ensure that abandonment operations were completed in a timely fashion and that no sites where abandonment operations had been initiated, but not completed, were left in an unsafe or unprotected condition.

The AEUB was also concerned with the volume of truck traffic required to transport the bitumen from individual well and pad sites to the central treating facility and the impacts associated with trucking related to projects of this type. The AEUB believed there was potential for pipelining, but noted that this would not occur without considerable research and development work, including field testing. Ranger testified that the transportation of the produced fluids by pipeline was presently not feasible due to the high viscosity and high sand content of the produced fluids.

The AEUB stated that it saw a need for additional information, in particular field data, to investigate and develop pipelining of bitumen and produced fluids. The AEUB stated that it expected major operators to play a lead role in the continuation of existing investigations and in the development of pipelining options. The AEUB urged Ranger to work with other oilsands primary bitumen producers respecting the development and application of pipelining and related technology, with a view to replacing trucking as the primary means of transporting produced fluids. The AEUB added that it expected Ranger to continue, in a timely manner, with collaborative efforts with other primary bitumen producers and agencies to research the fundamentals of produced fluids pipelining, to develop findings using pipeline test loops, and finally, to field test and apply development.

The AEUB stated that much greater attention to this work was required in order to reduce the impacts of trucking on the environment and on public safety. The AEUB cautioned that growth in primary production was only sustainable with a reduction of these impacts. Consequently, the AEUB required Ranger to report annually on its progress in researching, developing and applying pipelining technology.

Ranger supported its argument that its application would meet current air quality and emissions standards by presenting evidence developed through air dispersion modelling. The air dispersion model presented by Ranger was attacked by the interveners on the following counts:

- the modelling was based on unrepresentative sampling;

- the gas analyses of the samples collected were incomplete;

- the use of single value averages to represent broad ranges of components was fundamentally unacceptable; and 
- the model did not take into account cumulative effects from fugitive emissions from other industrial projects in the area.

The interveners argued that the modelling work and results were incomplete and unrepresentative and that it ought not to be used to assess the health impacts. The interveners' expert witness presented a theory that a chemical evolution was occurring, resulting in an aerosol plume being emitted from the tank vents. The interveners suggested that this plume contained sulphur compounds as well as other inorganic and organic chemicals. The expert noted that there was a "sulphur gap" between the measured total sulphur content of gas sample data reported by Ranger and the sum of sulphur contained in the individual sulphur compounds identified by the sample analysis. Ranger proposed to vent gas from the casing vents' tanks into the atmosphere, stating it was not economically feasible to incinerate the gas either at each well site or by collecting and transporting the gas to a central site.

The AEUB acknowledged that air dispersion modelling was a complex and involved process. The AEUB noted it was apparent Ranger's study could have been improved and that the concerns and questions raised by the interveners could have been avoided by taking greater care in sampling and analyzing the gas. The AEUB also observed that cumulative effects from other sources and other projects were not accounted for. However, notwithstanding the shortcomings of the air dispersion modelling, the AEUB was satisfied that Ranger's commitment to perform baseline and periodic monitoring for $\mathrm{NO}_{2}$ would confirm whether the air ambient guidelines were being met.

The AEUB rejected the interveners' theory of an aerosol plume being emitted due to a chemical evolution in the tank as unsubstantiated at the present time. The AEUB noted that this theory raised serious concerns in the minds of area landowners and stated that it would be prudent to conduct additional sampling or studies to provide factual information respecting the emissions from the tank vents. The AEUB stated that this issue, if it existed, would not be limited to Ranger facilities, but would be associated with all primary recovery schemes in the area. The AEUB strongly urged the Lakeland Operators Group to take this sampling work on as one of its first regional studies.

The AEUB agreed with Ranger that the economics associated with gas collection and the use or combustion of the gas did not support a blanket requirement to collect all casing and tank vent gases. The AEUB accepted Ranger's commitment to collect casing vent gas and to use at least 75 percent of this gas for fuel and engines for tank burners when the total casing vent gas volumes at a well or pad site exceeded $140 \mathrm{~m}^{3}$ per day on a sustained basis. The AEUB required Ranger to provide it with an annual report outlining the casing vent gas flow rate for all wells in the project areas and the steps that Ranger had taken to implement collection and use of casing vent gas at all sites where the threshold volume had been exceeded.

The AEUB stated that it was pleased that Ranger and other operators in the Cold Lake area had initiated steps to develop a public/industry liaison, or operators group. However, the AEUB expressed concern with the apparent lack of real progress with respect to initiating steps to address some of the regional concerns raised at this and other recent 
hearings in the Cold Lake area. The AEUB stated that it expected the operators group to take immediate action to develop and implement a monitoring program to assess the current ambient air and groundwater quality and noise and traffic in areas that would be impacted by new development. The AEUB approved Ranger's application and imposed a number of conditions.

In an appendix to the decision, the AEUB provided clarification with respect to how it treats voluntary commitments by an applicant. The AEUB noted that Ranger had undertaken to conduct certain activities in connection with its operations that were not strictly required by the AEUB's regulations or guidelines. The AEUB noted that these undertakings had been described as "commitments." when a company makes a commitment of this nature, it had satisfied itself that the activity benefited both the project and the public. The AEUB stated that it took these commitments into account when arriving at its decision, and it expected the applicant to fully carry out commitments or to advise the AEUB if, for whatever reason, it was unable to fulfill any commitments it had made.

The AEUB stated that when an applicant informed the AEUB that it was unable to meet a commitment it had made to interested parties, the AEUB would assess whether the circumstances of the failed commitment were sufficient to trigger a review of the original approval. The AEUB also ruled that affected parties had the right to ask the AEUB to review an approval if commitments made by an applicant remained unfulfilled.

\section{Shell CANADA Limited: COGENERATION Plant AND HydROgeN PIPELINE FORT SASKATCHEWAN AREA ${ }^{18}$}

This was an application by Shell Canada Limited ("Shell") for approval to construct and operate a $150 \mathrm{MW}$ natural gas fired cogeneration plant on its Scotford Upgrader Site adjacent to the Scotford refinery in Strathcona County. Shell also applied for approval to construct and operate approximately 8.7 kilometres of pipeline to transport hydrogen gas from the existing Dow Chemical facility to the proposed cogeneration plant.

One of the major issues of contention with local landowners was that of land use and zoning. Local landowners complained that there appeared to be different standards for large industrial operations and residential landowners when it came to approving developments. Landowners complained that while they were unable to obtain approval from the county for certain commercial developments, Shell appeared to have no similar problem.

The AEUB stated s. 619 of the Municipal Government Act ${ }^{19}$ gave AEUB licences and approvals precedence over land use bylaws or other planning instruments enacted by municipalities, as well as over decisions of local development appeal boards or other planning agencies. The AEUB explained that this provision did not empower the AEUB 
to assume authority for land use planning responsibilities given to municipalities. The AEUB stated that it accepted that in reaching decisions regarding energy projects, the public interest, as expressed in the energy statutes, obliged it to consider the impacts of energy-related activities on neighbouring lands. The AEUB further stated the potential effect of energy-related activities on lands situated near a project site could also be described generally as a land use issue because the potential effects could limit or impair the use and enjoyment to which owners may legitimately wish to put their lands. The AEUB ruled such "land use" issues were within its jurisdiction.

\section{CANADIAN 88 ENERGY CORP.: APPLICATION FOR A SOUR GAS WELL LICENCE OKOTOKS FIELD 20}

This was an application by Canadian 88 Corp. ("Canadian 88") for a sour gas well licence. The primary issue in this hearing was one of safety and regulatory oversight. One of the local interveners expressed concern with respect to how the public could be assured that companies were complying with all of the technical requirements without having to address such issues at a public hearing. Another intervener questioned whether there were regulatory processes in place to ensure compliance.

In response to this concern, the AEUB noted that it had documented its requirements in detail and expected oil and gas operators to meet them. While Guide 56 prescribed the information requirements for applications, other guides and interim directives set the requirements for casing, cementing, and other matters, such as well completion and servicing. The AEUB noted that it audits all critical sour well licence applications completely, and it expects applicants for non-critical sour wells to know the requirements and to meet them, but it audits only a portion of the total number of applications received based on certain triggers.

In the case of Canadian 88's application, the AEUB was concerned that the plans documented in the application for surface casing would not have met the minimum requirements, and that this was detected and modified to meet the requirements only as a result of scrutiny at the public hearing. The AEUB stated it was currently reviewing its requirements and processes for sour gas-related applications and that it intended to include consideration of this kind of problem in its review.

4. AVALANCHE ENERGY LIMTED: APPLICATIONS FOR A HOLDING, REDUCED SPACING AND REVIEW OF WELL LICENCES KEOMA/ENTICE AREA ${ }^{21}$

Two significant issues arose in the context of these applications: the impact of drilling on domestic water wells and the public consultation process. 
A number of landowners complained that the applicant's operations in the area had caused their well water to turn black and take on a sour gas odour. Avalanche Energy Limited ("Avalanche") maintained that its past drilling activities in the area had not affected domestic water wells. It noted that its gas wells in the Keoma area drinking water aquifers were covered by surface casing and cement, and it had had a water well drilling company drill the surface hole and cement the surface casing in place. Avalanche argued this method of installation ensured superior protection of drinking water. It also presented geologic evidence demonstrating a continuous subsurface pathway was unlikely to exist between the gas wells and water wells.

Avalanche maintained its wells could not be the source of the sour gas odour in the water wells, as sour gas horizons had not been encountered in its gas wells. Avalanche argued the discolouration and odour of the well water was the result of naturally occurring sulphate reducing bacteria. Before the hearing, the AEUB requested additional information and analysis of the domestic well water, including the collection of water samples, a sludge sample, two-hour pump tests, and video camera records at the wells.

At the hearing the landowners who had complained of a change in their well water stated that they had shock chlorinated their water wells and, therefore, did not accept Avalanche's argument that sulphate reducing bacteria had caused the water quality problem. Some landowners indicated that although Avalanche had retained experts to assist them with identifying the source of the water quality problem, they believed that Avalanche was more interested in absolving itself than in addressing the concerns of the landowners.

The AEUB noted the applicant had expended considerable effort in identifying reasons why its operations were not the source of the water quality problems. However, the AEUB found it surprising that Avalanche had originally failed to gather direct evidence to put before the AEUB supporting Avalanche's position that the water quality problems stemmed from bio-fouling by sulphate reducing bacteria. The AEUB also stated that it would have benefited all parties if the water quality concerns had been pursued with Alberta Environment so the cause of the deterioration in water quality could have been investigated earlier.

The AEUB concluded the evidence supported Avalanche's argument that the water wells were severely bio-fouled with iron and sulphate reducing bacteria, unlikely related to Avalanche's drilling activities. The AUEB noted that the interveners still believed Avalanche's drilling activity had impacted their water wells because the water quality had deteriorated shortly after the gas wells had been drilled. The AEUB recognized that Avalanche attempted to show that a causal relationship between the water quality problems and the drilling of gas wells did not exist, but that these attempts failed to convince the interveners that it would be safe to drill the proposed gas wells.

In order to provide additional assurance and to assist in ongoing relations, the AEUB directed Avalanche first to conduct a cement bond $\log$ at one well to confirm the integrity of cement operations and to monitor certain other water wells for thirty days following the drilling and completion of one of the gas wells. The AEUB directed Avalanche to 
discuss the specifics of the water monitoring program with the interveners, and it directed that this program include reconditioning one of the wells and the temporary installation of a pressure sensor to determine if the drilling, fracturing and completion of the gas well could be detected at the water well.

The next significant issue was that of public consultation. After hearing the evidence of the applicant and the interveners, the AEUB stated that it was apparent that there had been a decided lack of communication and understanding between Avalanche and the interveners, as well as among Avalanche's own staff and its contractors and agents. The AEUB noted it had heard evidence that Avalanche failed to disclose objections it was aware of in its application material properly, and that until the hearing Avalanche itself was unaware of when notification occurred regarding the reduced spacing application.

The AEUB appreciated that Avalanche recognized the limitations of the effectiveness of its public consultation program, which had been identified during the hearing, and had committed to take steps (such as retaining a public consultation adviser and organizing a community advisory committee) to attempt to minimize future concerns. The AEUB also believed these steps could also assist Avalanche in overcoming the mistrust that appeared to be prevalent among the interveners present at the hearing.

The AEUB was particularly concerned with Avalanche's perception of the requirements of Guide 56, which are intended to identify potential concerns or objections at the time of application. The AEUB noted that it set out clear direction in Guide 56 regarding its expectationsconcerning industry consultation responsibilities and public involvement. The AEUB also noted a company is expected to attempt to address concerns that are raised and to reconcile differences, if possible. The AEUB observed any objections or concerns that are raised and not resolved must be disclosed and thoroughly addressed in a nonroutine application.

The AEUB ruled that while Avalanche may have been attempting to address and resolve the residents' concerns, this in no way relieved Avalanche of the responsibility of notifying the AEUB that these concerns existed. The AEUB stated the applicant may not and should not judge the merit of the concerns raised; these are issues that the AEUB itself has statutory responsibility to consider. The AEUB also noted interveners must be responsible for reviewing information provided to them and discussing their concerns with applicants in order to reconcile differences, if possible.

The AEUB required Avalanche to review its internal procedures regarding notification and public consultation and to implement appropriate changes to ensure compliance with AEUB requirements. The AEUB directed Avalancheto provide satisfactory documentation to the AEUB audit team on its internal procedures in order to demonstrate a full understanding of and compliance with the public consultation requirements of Guide 56 applications. The AEUB stated that this submission was required prior to the issuance of approvals or reinstatement of the well licences. The AEUB also ordered Avalanche to audit all of the Guide 56 applications Avalanche had submitted to the AEUB since January 1,2000 , to confirm that notification and consultation requirements had been achieved. 


\section{PETRO-CANADA OIL AND GAS: STEAM-ASSISTED GRAVITY DRAINAGE Project Mackay River Project, ATHABASCa OILSANDS AREA ${ }^{22}$}

In this application to construct and operate a steam-assisted gravity drainage scheme for the production of crude bitumen from the McMurray Formation in the Athabasca oilsands area, the AEUB reaffirmed its support for various regional air quality initiatives and its desire that operators continue to participate actively in regional air quality research programs. The AEUB recognized the important role of industry operators in supporting regional initiatives and other multi-stakeholder initiatives to resolve regional air quality issues and establish management systems. The AEUB also took the opportunity to state that it continued to attach very high importance to the management of the cumulative environmental effects within the oilsands region.

\section{SOUTH ALBERTA ENERGY CORP.: REVIEW OF ABANDONMENT COSTS ${ }^{23}$}

In 1991 RTEC One Resources Inc. ("RTEC") proposed the transfer of a number of well licences to South Alberta Energy Corp. ("SAEC"). Prior to consenting to this transfer, the AEUB required that a private fund be established to provide for the future costs of abandonment and reclamation of wells acquired by SAEC. This fund was established and held by a trustee, and the transfers were completed in the fall of 1991. The provisions of the fund provided that it was to be used for the abandonment and reclamation of SAEC wells and stipulated that should SAEC not abandon and reclaim the wells, the fund was to be paid to the AEUB for that specific purpose.

Between 1995 and 1997 SAEC lost the right to produce certain of its wells, triggering the issuance of twenty well abandonment orders by the AEUB by September 1, 1995. On or about October 31, 1995, an individual purchased 100 percent of the shares of SAEC, becoming its sole shareholder and director. The SAEC shareholder then purported to transfer the ownership of the SAEC shares to South Alberta Energy Group ("SAEG"), a corporation in which he was the sole director and shareholder. The AEUB subsequently issued two more well abandonment orders to SAEC.

By early 1997 the twenty-two wells remained unabandoned, and additional wells and related facilities were ordered abandoned. In total eighty-nine wells licensed to SAEC were ordered abandoned by the AEUB. In addition, nine pipeline licences granted to SAEC, encompassing 101 lines, were ordered abandoned. SAEC failed to comply with the abandonment orders within the allotted time, and the AEUB corporate compliance group solicited bids from various abandonment firms and completed the abandonments on its own initiative. The abandonments were completed in June 1999.

South Alberta Energy Corp., Greg Justice, 693040 Alberta Lid., and Marc Dame, Review of Abandonment Costs Order No. ACO 98-I (17 July 2000), 2000-51 (A.E.U.B.) [hereinafter South Alberta Energy Corp.]. The shareholder sought leave to appeal from this decision. Leave to appeal was granted by Wittmann J.A. on October 10, 2000: [2000] A.J. No. 1167 (C.A.), online: QL (AJ). 
On October 30, 1996, SAEG sold 100 percent of its SAEC shares to 693040 Alberta Ltd. On August 24, 1998, the corporate compliance group issued an invoice to SAEC, the individual who purchased the SAEC shares, 693040 Alberta Ltd., and the individual who had executed the sale agreement of SAEC shares to 693040 Alberta Ltd. No payment was made by any of the parties. On October 5, 1998, the AEUB issued abandonment costs order 98-1 ("ACO 98-1") ${ }^{24}$ naming the SAEC shareholder, 693040 Alberta Ltd., and the individual who had executed the sale agreement of SAEC shares as persons in control of SAEC. It also declared them to be jointly and severally liable, along with SAEC, for the payment of the abandonment costs associated with the wells and related facilities.

The SAEC shareholder, 693040 Alberta Ltd., and the individual who had executed the sale agreement of SAEC shares requested that the AEUB review costs order ACO 98-1. After making a number of comments regarding the consistency of evidence tendered at the hearing, the AEUB ruled that the agreement of August 30, 1996, between 693040 Alberta Ltd. and SAEG had been terminated by mutual agreement of the parties. The AEUB stated that s. 20.1 of the Oil and Gas Conservation $A{ }^{25}$ must be read broadly, as the plain words have a wide meaning. The AEUB stated s. 20.1 and its companion sections provide that any person exercising actual control of the licensee or working interest participant may be liable for abandonment costs.

The AEUB remarked that the existence of a binding agreement evidencing the transfer of ownership and control may establish the fact of effective actual control required by $s$. 20.1, but it is not the only indicium of such control. The AEUB ruled that real, effective and practical control over a company's business affairs will amount to control as contemplated in s. 20.1, and it may exist in a wide variety of settings and arrangements. The AEUB stated that control was ultimately found in the power to direct the business of a company and make decisions that would be complied with and acted upon by a company. The AEUB noted that each case had to be reviewed on its own facts and circumstances in order to determine the entity effectively exercising this authority.

The AEUB conducted a thorough examination of the various agreements, and it also heard, and presumably considered, extrinsic evidence regarding these agreements. The AEUB also noted s. 20.1 prevented the AEUB from naming previous working interest participants in abandonment cost orders if the current working interest participant was the licensee of the facility in question. Accordingly, the AEUB found that it was precluded from naming the previous owners of SAEC in any abandonment cost order issued against SAEC.

\section{NYCAN ENERGY CORP.: REVIEW OF AN OFF-TARGET PENALTY, NYCAN FORTY MILE AREA ${ }^{26}$}

Nycan Energy Corp. ("Nycan") applied for a hearing to consider the need to apply an off-target penalty to its 02/03-23-007-10 W4M well. At issue in this hearing was the 
appropriate interpretation of Interim Directive $94-2^{27}$ and ss. 4.060(5) and 4.060(6) of the Oil and Gas Conservation Regulations. ${ }^{28}$ These set out the "first well" policy under which a well meeting certain criteria is exempt from an off-target penalty.

The Canadian Association of Petroleum Producers ("CAPP") filed a submission expressing a general interest in ensuring consistent and predictable interpretation and application of AEUB policies. CAPP argued that an abandoned well in respect of which the mineral rights had reverted to the Crown should not be considered the "first well" in a new pool and should not be considered capable of production.

The AEUB noted that ID 94-2, which set out the AEUB's policy with respect to offtarget penalties and first wells, had been given statutory recognition by the enactment of ss. 4.060(5) and 4.060(6) of the Regulations. The AEUB noted that these sections of the Regulations differed slightly from ID 94-2 because the Regulations require that a first well be the well in a new pool with the earliest spud date that is capable of production; whereas ID 94-2 defines a first well as the well with the earliest spud date that is capable of production. The AEUB stated that while ID 94-2 did not specifically differentiate between "pool" and "new pool," it did suggest the intent of the policy was to reward those who took the initiative to explore for a new pool.

The AEUB noted that both ID 94-2 and the Regulations specify that the first well designation applies only to wells spudded on or after April 1, 1994. Consequently, the AEUB noted, it would be possible for a well drilled after this date to be precluded from the first well consideration by a well drilled prior to the effective date of the interim directive. Additionally, the AEUB noted that where wells containing a well with first well status are coalesced, only one well will retain first well status.

On September 30,1999, Nycan submitted an application requesting that the AEUB apply an off-target penalty to the Sphere Energy Inc. ("Sphere") Forty-Mile 15-14-007-10 W4M well. This well was off-target towards section 23-007-10 W4M. Nycan had already directionally drilled the $02 / 03-23$ well in section 23 to a bottom hole location that was off-target towards section 14. Nycan submitted that the Sphere 15-14 well was producing from the same pool as the Nycan well and requested that the AEUB assign an off-target penalty to the Sphere 15-14 well and classify the Nycan 02/03-23 well as the first well in a new Fish Scale pool.

AEUB staff determined that both wells were producing from the same pool, which was subsequently designated as the Forty-Mile Fish Scale A Pool. The AEUB assigned an offtarget penalty to the Sphere 15-14 well and suspended the off-target penalty assigned to the Nycan 02/03-23 well because it was the first well in the newly-designated two-well pool.

On February 23, 2000, Sphere submitted an application requesting a review of the first well status given to the Nycan 02/03-23 well. Sphere submitted that the newly-designated 
pool was known to exist long before the drilling of either the Sphere 15-14 or Nycan 02/03-23 wells and that the assignment of first well status to the Nycan 02/03-23 well was inappropriate. In support of its argument, Sphere cited the BVX Foremost 10-23-007-10 W4M well, which had been drilled in 1977, had been drill stem tested, but had not been completed and had been abandoned.

The AEUB undertook a pool review, resulting in an expansion of the Forty-Mile Fish Scale A Pool to include several additional wells, including the BVX Foremost 10-23 well. The AEUB stated that while this 10-23 well (which had been drilled in January 1977 , prior to the "first well" policy) may not have been considered capable of production, it did identify the existence of hydrocarbons and the presence of a pool as defined in the Oil and Gas Conservation $A c t .{ }^{29}$ As a result, the AEUB revoked the first well status from the Nycan 02/03-23 well and applied an off-target penalty. Nycan requested a hearing under s. 43(1) of the Energy Resources Conservation Act. ${ }^{30}$

The AEUB identified the following issues:

- the intent of ID $94-2$;

- the qualification of the Nycan well as a first well for the purpose of off-target penalty administration and how well data acquired prior to April 1, 2000, affects first well determination; and

- the need for an off-target penalty on the Nycan well.

Nycan stated that due to surface topography, the optimum surface location for drilling a well to access the Fish Scale zone in section 23 required the well to be directionally drilled. Nycan testified that at the time it was considering drilling the 02/03-23 well, it reviewed the wells in the area of section 23 and determined, according to its interpretation of the "first well" policy, that no other well had been completed and tested to show that it was capable of producing gas from the Fish Scale zone on a sustained basis at commercial rates as required by the definition of "first well." Accordingly, Nycan concluded that its well would be the first well in the pool and would not be subject to an off-target penalty.

Nycan stated that there was sufficient geological control to show that pay existed in the target area and that an on-target well could have been drilled, but it would have been significantly more difficult and expensive to drill. Nycan also confirmed that its well had been licensed with a Lahee classification of "development," rather than "new pool wildcat," as a result of an internal error. Nycan testified that in its view the well was clearly an exploration well, but Nycan did not consider it necessary to change the classification until that classification became a problem - when Revenue Canada would not recognize a high-risk classification for relief from income tax requirements. Nycan testified it had requested the AEUB to change the Lahee classification from development 
to exploratory, but this application was turned down on the basis of the AEUB's pool review.

Nycan argued that in order to be considered a first well, a well had to have not just the earliest spud date, as Sphere suggested, but must have the earliest spud date, be the first well to be completed, and be the first well to be tested to demonstrate the ability to produce gas at a commercial rate on a sustained basis. Nycan argued that Sphere's interpretation would make it impossible for operators to arrange their affairs as they would have to take into account the risk that a dormant well, which may have been spudded years ago, might be recompleted, tested and designated the "first well."

Nycan also argued that the relevant time for gauging whether a test demonstrates that a well has the ability to produce gas at a commercial rate on a sustained basis is when the test is done. Nycan argued that because the Foremost BVX 10-23 well had never been completed and did not have a suitable test that demonstrated the ability to produce gas at a commercial rate on a sustained basis, it could not displace the Nycan 02/03-23 well as the "first well" in the pool.

Sphere argued that the Nycan well was not entitled to off-target penalty relief both because it was not an exploratory well and because another well pre-empted the 02/03-23 well status as first well in the pool when it was completed and put on production from the pool. This well, the 16-21 well, had been spudded earlier than the Nycan well, but it had been recompleted in the relevant zone after the Nycan well. Sphere noted the Regulations did not define "new pool" but argued that it was clear from ID 94-2 that the first well policy was intended to apply only to exploration wells. Sphere also argued that whether the old 10-23 well would qualify for status as first well in the pool was irrelevant and that what was important was that the 10-23 well identified the pool in question.

The AEUB noted that the degree of regulatory equity protection expected by industry, and the specific rules, must be generally endorsed and clearly understood. It noted that ID 94-2 was a product of extensive industry and government consultation and included many diverse views. The AEUB observed that for the first well program to be successful, a company proposing to drill an exploratory well had to be able, with due diligence, to review readily available well information and be able to determine reasonably whether its well would meet the criteria of "first well."

The AEUB confirmed that the intent of the first well policy was to support exploratory drilling as a special case. It added most "first wells" would be expected to have an exploration type Lahee classification, but the first well policy did not preclude the possibility that a development-type well may in fact be the first well to identify a new pool and show commercial capability. The AEUB agreed with Nycan that a "first well" must be:

- $\quad$ spudded on or after April 1, 1994;

- the first well to encounter or discover the pool in question; and 
- the first well capable of production in the pool in question.

The AEUB rejected Sphere's argument that a first well need only be the first well spudded in the pool. The AEUB ruled that there was, in its opinion, sufficient ambiguity in the first well program to warrant a review by AEUB staff, CAPP and the Small Explorers and Producers Association of Canada ("SEPAC"). The AEUB suggested these parties might wish to examine the merits and regulatory burdens of extending the first well policy into more medium risk situations, or other scenarios. Notwithstanding this identified ambiguity, the AEUB stated that the existing rules were sufficient to maintain the program and to render a decision on Nycan's application.

The AEUB concluded that the 10-23 well (spudded in 1977) demonstrated the presence of hydrocarbons and thus a pool. The AEUB noted that Nycan's well should have benefited from this information and, therefore, did not represent the high risk exploratory drilling expected in the first well policy. The AEUB stated that although the 02/03-23 well was the first well spudded after April 1, 1994, to demonstrate capability, it did not find a new pool and did not, therefore, meet the criteria for "first well."

The AEUB rejected Sphere's suggestion that once a well was spudded it put an indefinite hold on "first well" status for all potentially productive zones such that a test many years later could pre-empt another well that had enjoyed "first well" status. In the result, the AEUB affirmed the off-target penalty on the Nycan well. ${ }^{31}$

\section{SHELL CANADA LIMTTED: APPLICATION FOR A WELL LICENCE, SHELL PCP FERRIER 7-7-38-6W5, FERRIER FIELD ${ }^{32}$}

This was an application by Shell Canada Limited ("Shell") for a well licence to drill a Level 4 critical sour gas well in the Caroline area. At the start of the decision, the AEUB noted this application considered whether the development of the proposed sour gas well would be in the public interest, and it included an examination of the unique topographic and demographic conditions in the vicinity of the proposed well in conjunction with the potential release rate from the well under reasonable worst-case conditions. This was the first of several times the AEUB stressed the unique nature of the circumstances surrounding this application. Ultimately, the AEUB found that the Emergency Response Plan ("ERP") proposed by Shell had not adequately addressed the unique conditions surrounding the application, and because public safety could not be "acceptably assured," 33 the AEUB denied the application, without prejudice to any future application.

On the issue of the need for the well, the AEUB stated that while the economic impact of any one well may be quite small on a provincial basis or to a company as large as

33 Ibid. at para. 1. 
Shell, the AEUB had in the past concluded that the aggregate public economic benefits from energy development at the provincial level can outweigh negative effects at the local level, provided that they are properly managed and mitigated. Continuing, the AEUB observed that to reach such a conclusion for any particular well, the AEUB must be convinced that the well could be developed in a manner that would not have unacceptable impacts on local residents. The AEUB noted that the circumstances surrounding any well will differ, and unique features of a particular region may result in unacceptable adverse effects that would be considered acceptable in other circumstances.

One of the more contentious issues in this hearing was the appropriate model for modelling potential dispersion patterns. Shell had selected the GASCON 2 model, based upon the assumption that any plume resulting from an uncontrolled flow of sour gas from the well would be neutrally buoyant. Shell argued the use of SLAB, a dense gas dispersion model for a heavier-than-air gas mixture advocated by a large number of local interveners, was not appropriate in the circumstances.

The interveners did not agree with Shell's use of the GASCON 2 model and argued this model could not appropriately take into account effects such as gravity slumping, reduced air entrainment associated with a denser-than-air plume, and the thermodynamics of evaporating liquids. The interveners argued the SLAB model was the more appropriate model because it could take account of the effects of a dense gas. The David Thompson Health Region argued Shell's risk assessment was also based on an unrealistic assumption of immediate ignition of a well release and that the criteria proposed by Shell for ignition of the well would be very difficult to interpret and would introduce a significant amount of time into the decision to ignite. Local interveners also expressed concern with the validity of Shell's risk assessment and complained that immediate ignition criteria were not written into Shell's ERP.

The interveners told the AEUB that they had not provided an alternative risk assessment in their submission, but had chosen only to critique Shell's assessment. They stated they had done this so that the AEUB could not simply choose a value between Shell's assessment and the interveners' assessment.

The AEUB ruled it would not be reasonable to predetermine the appropriate dispersion model to be used in all regulatory applications. The AEUB observed that it believed input assumptions and calculation tools needed to be appropriately, but not unreasonably, conservative and that the assumptions should be based on plausible worst-case release scenarios and potential plume dispersion conditions. The AEUB stated that where there was ambiguity with respect to the appropriateness of any model, the more effective approach would be to evaluate the release using the various alternative models. The AEUB stated that in this particular case it would have found it useful to have a comparison of the results of such alternative modelling, including a discussion of the implications of the input assumptions and of the relative extent to which each of the alternatives may over- or under-predict possible actual concentrations.

The AEUB agreed with Shell that it was possible an uncontrolled release would result in the plume acting in a neutrally buoyant fashion. The AEUB stated, however, that there 
was also the potential for the formation of hydrocarbon liquid aerosols in the plume, and this warranted assessment of dense gas plume behaviour as well. The AEUB ruled that the implications of both dense gas and neutrally buoyant plume calculations could have been used to describe a range of potential outcomes of an unignited sour gas release. The AEUB remarked that, as a minimum, where source conditions suggest there may be a reasonable potential for the formation of a dense gas plume, and where the applicant prefers to use only one modelling methodology, the AEUB expected that the more conservative methodology would be used in determining the potential gas behaviour.

The AEUB stated that additional clarification of acceptable protocols for air dispersion modelling would be beneficial for both applicants and interveners, and as well a forum other than a project-specific public hearing would be more conducive to productive debate among experts. The AEUB stated that it intended to pursue this issue further, possibly as part of the ongoing public safety and sour gas review.

On the basis of its estimated release rate, Shell calculated an emergency planning zone ("EPZ") of 19.2 kilometres. However, Shell applied for a greatly reduced four kilometre EPZ and a corresponding eight kilometre emergency awareness zone ("EAZ"). In the event of an uncontrolled release, Shell proposed that its decision to ignite the well would depend on a number of factors, including whether or not the EPZ had been evacuated.

Many interveners expressed concerns regarding Shell's proposed ERP, including the adequacy of a four kilometre EPZ. Shell also proposed the county be responsible for certain aspects of emergency response; interveners questioned the ability and capability of the county to perform these obligations.

The AEUB identified the following four key issues with respect to evaluating the adequacy of Shell's emergency preparedness:

- the acceptability of the proposed reduction of the calculated EPZ;

- the ability of the local government to carry out its proposed role in the ERP;

- the ability of the ERP to address unique individual needs; and

- the impact of ignition times on the ERP assumptions.

The AEUB remarked that in reaching its conclusions, it had been particularly cognizant of the interveners' evidence regarding the unique features of the area. The AEUB pointed out that an effective ERP for the area needed to address these unique features, including features not normally faced by an applicant. The AEUB pointed out that in this case, the presence of the Clearwater River created a significant barrier to effective evacuation in the case of an emergency. The AEUB also observed that communication with the public in the area might also be difficult under emergency conditions, since many residents were transitory or did not have telephones. The AEUB also accepted that there were a number of individuals who could be particularly sensitive not only to the effects of an uncontrolled well release, but also to the stress that such an event might introduce. While 
the AEUB noted that Shell had tried to address this issue by offering to remove these individuals from the area during drilling and testing, the AEUB held this solution had its own potentially significant impacts on the health of these individuals.

With respect to Shell's proposed reduced four kilometre EPZ, the AEUB stated that it required an application for use of a reduced EPZ be submitted for review and approval at the onset of a project and prior to public consultation taking place. The AEUB also added it generally expected an application for use of a reduced EPZ to contain detailed supporting documentation of the reasons why the proponent believed that the calculated zone would be unmanageable, along with details of all enhanced public protection measures and other safety features proposed to ensure protection of the public in the event of an emergency. The AEUB noted that Shell had not applied for use of a reduced EPZ in advance but chose to make the proposed reduction part of its application to be considered at the public hearing.

The AEUB ruled it was not convinced from the evidence at the hearing that the use of a reduced EPZ had been adequately justified by Shell. The AEUB remarked that there remained significant questions, based on the information provided by Shell and the interveners, as to whether the safety enhancements proposed by Shell would be sufficient to address the unique area issues. The AEUB particularly singled out Shell's proposed ignition criteria, which were dependent on factors such as status of evacuation and monitoring results, rather than agreement to immediate ignition of an uncontrolled release of $\mathrm{H}_{2} \mathrm{~S}$, regardless of other factors.

The AEUB also ruled that it did not consider Shell's draft ERP to be a comprehensive site-specific plan. The AEUB expressed concern that Shell had been unable to provide evidence sufficient to convince the AEUB that adequate support services would be available should an incident occur. The AEUB stated that while it was clear discussions had taken place between Shell, the county, and other agencies, the AEUB had not been able to confirm from the information provided by Shell that the potentially significant responsibilities of the local government set out in Shell's proposed ERP had been agreed to or could be met. The AEUB considered that this brought into question the efficacy of Shell's ERP.

The AEUB also remarked that Shell had not demonstrated a clear understanding of the AEUB's definition of immediate ignition, and it was concerned about Shell's reluctance to commit to meeting the AEUB's expectation. The AEUB pointed to the linkage between Shell's ignition criteria, the successful evacuation of the public, and the results of air monitoring. Shell had also proposed to further delay ignition in order to continue to attempt to control the well if it believed that evacuation of the area had been accomplished. The AEUB held that, given Shell's proposed reduced EPZ, the historically significant transient and recreational usage of the area, and the public sensitivities within the area, Shell's proposed ignition criteria were unacceptable for the project.

Another significant issue in this hearing was that of public consultation. The AEUB noted that Shell had assessed the potential sensitivity of the public in the area by comparing it to other areas where similar sour gas wells had been proposed. Shell's 
assessment identified the area as one with significant existing oil and gas activity. Consequently, Shell decided to initially advise local residents of its proposal to drill the sour gas well through a mail-out of its public information package. Shell testified that it soon became aware that there was strong opposition by the local community to the proposed well.

Shell acknowledged that it had misread the comfort level of the community with sour gas development. Shell told the AEUB it regretted the approach it had initially taken to public consultation, and Shell conceded it may also have offended people by the timing of its information package, which was sent out in late 1998, with drilling proposed to begin in January 1999. Shell also agreed that another contentious issue arose by virtue of the fact that Shell had already negotiated for and agreed upon a surface location for the well.

The AEUB stated that it was clear that in designing its initial public consultation program Shell had significantly underestimated the concerns of area residents. The AEUB stated that it was also clear that Shell made a number of additional errors in the early stages of its consultation program. The AEUB stated that the combination of these factors resulted in a serious erosion of public trust in Shell from the outset. The AEUB accepted the evidence of interveners who stated that these initial errors very likely made future effective consultation almost impossible in spite of Shell's subsequent efforts.

The AEUB also recognized that some members of the community chose not to engage in Shell's initial consultation attempts. The AEUB noted that while this was certainly the right of members of the community, they should understand that the AEUB only required proponents to make every reasonable attempt to carry out consultation, and it would be very unlikely for the AEUB to find that an applicant had failed to meet the AEUB's expectations for consultation if the public chose not to participate. The AEUB stated that, although Shell eventually met the AEUB's expectations for consultation, Shell's failure to meet these expectations earlier in its public consultation process likely led to the significant widespread opposition to the application. Additionally, the AEUB stated that the uniqueness of the area meant additional efforts were required by Shell to ensure that communications with the public were maintained and to assist the public with individual issues.

In its decision, the AEUB also dealt with an issue respecting the use of experts. The AEUB encouraged the use of experts to assist in mounting an effective and focused intervention. The AEUB stated that it expected experts to meet with their clients to provide them with their experience and advice so that the public can gain understanding and clarification on complex issues. The AEUB was very concerned to learn that during the course of the hearing, the experts retained by counsel for the interveners had not consulted with the interveners themselves. The AEUB noted that, as a result, the interveners were not well informed about the issues and facts presented on their behalf by their experts.

The AEUB acknowledged that the interveners believed that contact with their experts was ill advised and could potentially taint the evidence of the experts. The AEUB 
observed that this was not its experience. Professionals and scientists before the AEUB generally put forward a position rooted in research and fact, not popular opinion. The AEUB added that the educational component experts could offer their clients prior to the hearing was a key component of the expertise they had. The AEUB stated that an important dialogue between the interveners' experts and the interveners that failed to occur contributed to a much lengthier hearing process on certain issues and a less meaningful examination of the issues both by the public and the AEUB.

The AEUB also expressed concern regarding confidential information. Prior to the hearing, the parties had engaged in an unsuccessful mediation. The AEUB was concerned that during certain areas of testimony, witnesses for both Shell and the interveners declined to respond to questions they perceived to be covered by the confidentiality agreement, which was entered into as part of the mediation process. The AEUB stated that in some instances this made it difficult for it to gather important and relevant data needed to appraise the project and the public's reaction to it. The AEUB remarked that the confidentiality provisions also hindered the ability of the parties to communicate the results of their discussions back out to the community as a whole.

The AEUB acknowledged it was important that participants engaging in any form of dispute resolution process have regard for the information that eventually will need to be communicated to other interested parties, particularly to the AEUB during its hearing process. The AEUB noted that while it wished to encourage industry and the public to participate in meaningful and open dialogue to discuss and resolve issues, the AEUB had to be able to explore issues within its jurisdiction in consideration of any application.

The AEUB ruled that Shell's proposed drilling program met the AEUB's requirements for critical sour gas wells and was designed to deal with the reasonably foreseeable factors that could lead to the uncontrolled release of sour gas. However, the AEUB ruled that it was equally clear that Shell had been unable to convince local residents of this, and Shell's public consultation program, by its own admission, had a very inauspicious start. The AEUB noted that despite significant efforts, Shell had been unable to repair the damage. The AEUB stated the lack of trust, evidenced by interveners, also appeared to have had an impact on Shell's ability to design an effective ERP. The AEUB called Shell's approach to modelling plume dispersion "questionable."

With respect to Shell's proposal to reduce its EPZ, the AEUB noted the unique area topography and demographics that Shell was forced to address in creating its ERP. The AEUB concluded that a significantly expanded ERP in this region would be difficult, although certainly not impossible, to manage. The AEUB stated it was not prepared to accept Shell's view that it could rely on early evacuation to ensure public safety in the region. The AEUB ruled that Shell's proposal not to invoke immediate ignition was unacceptable. The AEUB also held that the offer by Shell to evacuate hypersensitive individuals from the region while drilling through the critical zone would not adequately address the unique concerns of these individuals. The AEUB acknowledged that this approach had been and would likely continue to be effective in the future, but stated that it was not appropriate in this particular case. 
Taking into account all of the evidence before it, the AEUB was unable to reach the conclusion that public safety could be adequately protected. The AEUB stated that the unique combination of the potential size and $\mathrm{H}_{2} \mathrm{~S}$ release rate of the proposed well, the limited and difficult egress from many of the area residences (in some cases, towards the well), the relatively large and diverse population with a high probability to be out of doors, and the potential presence of hypersensitive individuals proximal to the well all led to the conclusion that, in the event of a reasonable worst-case scenario, the ERP proposed by Shell could not assure public safety. The AEUB considered whether or not it would be prepared to approve the requested well licence if certain additional conditions were met but concluded, based on the evidence before it, that this approach would not be appropriate. Accordingly, the AEUB denied the application.

\section{GULF CANADA RESOURCES LIMITED: REQUEST FOR THE SHUT-IN OF ASSOCIATED GAS, SURMONT AREA ${ }^{34}$}

In November 1996, the AEUB received a submission from Gulf Canada Resources Limited ("Gulf") requesting that the AEUB order the shut-in of associated gas production from the top of the Wabiskaw Member to the base of the McMurray formation on its Surmont oilsands leases. ${ }^{35}$ Gulf argued that pressure depletion of the gas pools and association with the oilsands zones would adversely affect the recovery of bitumen by the steam-assisted gravity drainage ("SAGD") process to the extent that the bitumen might not be recoverable.

The AEUB held a general inquiry into the matter and issued its gas/bitumen inquiry report in March 1998. After the report was issued, Gulf amended its request to include the shut-in of associated gas from wells within a three-section buffer area surrounding its Surmont leases. Petro-Canada Oil and Gas made a submission in support of Gulf's request, while the Surmont producers group ("SPG") opposed Gulf's request.

The AEUB believed that the bitumen resources on Gulf's Surmont leases were approximately 15 billion barrels, and if 35 percent to 50 percent were ultimately recoverable, as suggested by Gulf, this would result in the production of 5.25 billion to 7.5 billion barrels of bitumen. The AEUB noted that only about 12 billion barrels of lightmedium crude oil have been produced in Alberta to the end of 1998. Accordingly, the AEUB noted that the bitumen resources in Gulf's Surmont leases represented a significant energy resource for the province, which the AEUB believed warranted consideration for the protection of future development. The AEUB accepted estimates for remaining recoverable gas reserves in the requested gas shut-in area of 95 billion to 180 billion cubic feet, which on an energy basis (i.e., 17 million to 32 million barrels of oil equivalent) was

34 (March 2000), 2000-22 (A.E.U.B.).

35 The AEUB's authority to regulate concurrent gas and bitumen production is found in the Oil and Conservation Amendment Regulation, A.R. 47/99 and Oil Sands Conservation Amendment Regulation, A.R. 48/99. The Alberta Court of Appeal has recently confirmed that both A.R. 47/99 and A.R. 48/99 are within the AEUB's authority to enact regulations (see Giant Grosmont Petroleums Ltd. v. GulfCanada Resources Ltd., [2001] A.J. No. 864 (C.A.) online: QL (AJ), Pickard and O'Leary JJ.A. concurring, Conrad J.A. dissenting). An application for leave to appeal has been filed with the Supreme Court of Canada. 
much less than the potentially recoverable bitumen - approximately one-half of one percent.

The AEUB believed that all of the Wabiskaw-McMurray gas being produced by wells on the Gulf Surmont leases is or had the potential to be associated with the underlying bitumen. The AEUB stated that because of the limited amount of applicable field experience, it believed that reservoir modelling was the best tool available to evaluate the effect of associated gas production on SAGD bitumen recovery. The AEUB believed that reservoir modelling reasonably demonstrated that producing associated gas in the Surmont area would likely have a detrimental effect on SAGD bitumen recovery, and that this detrimental effect increased with decreasing gas pool pressure. The AEUB also stated that it believed the reservoir model predictions might underestimate the effect of associated gas production on SAGD bitumen recovery, as the models used were not able to account for all of the risk factors identified by Gulf and Petro-Canada. The AEUB also ruled that it was not prepared to rely on the possibility of re-pressuring the depleted gas zones by gas injection as a reason to allow continued gas production until it had been demonstrated that this was feasible and practical.

The AEUB acknowledged that the SAGD process for recovering bitumen could result in the loss of associated gas into the bitumen zone and the loss of evolved solution gas from the bitumen zone into the overlying gas zone. However, because there was very little evidence submitted on this issue, the AEUB found that it was not in a position to draw any conclusions in this regard and directed that this issue be dealt with in any future applications to the AEUB for SAGD schemes for the recovery of bitumen.

The AEUB rejected the argument of the SPG that the potential for sterilization of the bitumen resource was not a matter of public interest. The AEUB noted that accepting this argument could result in the AEUB not considering many situations where resources could be effectively sterilized under any reasonably foreseeableeconomic conditions. The AEUB recognized that it could take 100 to 200 years to produce the bitumen on Gulf's Surmont leases, but it did not believe that it was reasonable and prudent to "force" bitumen development by requiring leaseholders to demonstrate, along with performance requirements, commitments to bitumen projects within a given time frame.

The AEUB accepted the potential value of the bitumen resources significantly exceeded the value of the remaining gas reserves in the Surmont area and stated that it would not be in the public interest to accept a possibility of sterilizing a vast bitumen resource by allowing continued gas production.

The AEUB acknowledged that shutting in gas production of Surmont would have a significant impact on the SPG and might require some complementary action. The AEUB noted that s. 91 of the Oil and Gas Conservation $\mathrm{Act}^{36}$ gave the provincial Cabinet the power to direct the AEUB to proceed to prepare a scheme to compensate persons who are 
injured or suffer a loss by reason of any orders made pursuant to the $A c t{ }^{37}$ The AEUB concluded that continued production of associated gas presented a significant risk to future bitumen recovery from the Gulf Surmont oilsands leases and granted Gulf's request in part. The AEUB ordered the shut-in of Wabiskaw-McMurray gas production effective May 1, 2000, from 146 of the 183 wells that Gulf requested be shut-in.

During the course of the hearing, the AEUB determined that in order to consider Gulf's request properly, a significant amount of confidential information would be required to be produced at the hearing. The parties possessing the confidential information did not agree to produce it voluntarily, arguing that it was commercially sensitive and had proprietary value. Accordingly, the AEUB issued an Order to Produce Documents, which identified the persons entitled to access the information and the conditions upon which limited access would take place. The AEUB issued two editions of its decision. The confidential edition, containing the AEUB's review and consideration of the confidential information, was made available only to those parties who had signed the declaration and undertaking not to disclose, as described in the Order to Produce Documents. The public edition of the decision only presents a summary of the AEUB's views and conclusions on those issues where confidential information was considered.

\section{CANADIAN WESTERN NATURAL GAS COMPANY LIMTED: 1998 GENERAL RATE APPLICATION PHASE II ${ }^{38}$}

In the context of Canadian Western Natural Gas Company's ("CWNG") rate design, a number of parties filed evidence suggesting that CWNG's proposed rates did not promote the transition to a competitive marketplace. A number of parties expressed significant concern that the structure of the proposed rates prevented core customers (i.e., residential and small commercial customers) from evaluating competitive alternatives. It was suggested that this discouraged the entry of other participants in what could otherwise be an open and competitive retail marketplace. A number of parties suggested that the AEUB should direct CWNG to take necessary steps to eliminate the existing barriers to core market competition.

CWNG took the position that while maintenance of the status quo would best protect consumer interests by ensuring the lowest cost and most efficient service, CWNG was prepared to follow directions of the AEUB. CWNG also expressed concern that some of the "customer choice" proposals favoured by various interveners could compromise CWNG's ability to recover its approved revenue requirement. CWNG stated that it was

On May 24, 2000, the provincial Cabinet issued Order-in-Council 196/2000, directing the AEUB to prepare a scheme for the provision of compensation for persons having an interest in the petroleum and natural gas rights affected by the AEUB's decision ordering the shut-in of gas production from 146 wells in the Surmont area. However, McMahon J. has since ruled that O.I.C. 196/2000 was ultra vires the Lieutenant Governor in Council's authority and that the order is of no force and effect. This ruling was based on the fact that the order specifically excluded the Crown as recipient or payor of such compensation (see Gulf Canada Resources Ltd. v. Alberta, [2001] A.J. No. 387 (Q.B.) online: QL (AJ)).

38 (13 June 2000), 2000-16 (A.E.U.B.). On December 13, 1999, Canadian Western Natural Gas Company Limited changed its name to ATCO Gas and Pipelines Ltd. 
prepared to take the steps necessary to remove its carbon storage facility and related production from regulation and to move to the deferred gas account ("DGA") all costs directly related to the provision of gas supply services.

By way of background, on the issue of customer choice, the AEUB noted that the provincial government had enacted the Gas Utilities Core Market Regulation ${ }^{39}$ in 1995. The objectives of this regulation were:

- providing smaller customers with a choice of gas supplier and introducing competition into a monopoly market;

- ensuring cost accountability for direct sales participants and ensuring that direct sales were not subsidized;

- ensuring reliability to minimize risk of supply failure; and

- maintaining the utility as a distributor of natural gas to consumers.

The AEUB noted that, in general, the parties agreed that CWNG's existing rate structure masked market price signals and inhibited core customers from evaluating competitive alternatives and making informed choices. The AEUB agreed that steps needed to be taken to initiate a process that would continue to move towards removing existing barriers to customer choice. The AEUB stated that it considered that this process should unfold in a measured fashion, preserving the integrity of the utility and recognizing the requirement of those consumers who did not wish to enter the competitive marketplace.

The AEUB found that there was general agreement that the elimination of at least some of the barriers to customer choice, inherent in CWNG's rate structure, would be most effectively achieved by the unbundling of services. The AEUB noted that although there was a consensus that unbundling should be phased in initially, within the regulatory umbrella, there was a range of opinion regarding the extent to which services should be unbundled. In the result, the AEUB directed that there be a collaborative process, conducted in a manner consistent with the principles of the AEUB's negotiated settlement guidelines. The AEUB stated that in the context of this collaborative process it expected CWNG to bring forward for examination an unbundling proposal that incorporated the following features:

- identification of the sales portion of gas supply, gas management, and production and gathering costs it proposed to be moved into the DGA;

- identification of delivery service costs, including customer service costs, capable of being provided on a competitive basis; and

- identification of the costs of storage. 
The AEUB noted that the evidence before it clearly indicated that the issue of transferring gas supply costs from the distribution rate to the gas cost recovery rate ("GCRR") was a priority. The GCRR is the rate pursuant to which gas utilities recover from their customers the cost of gas. An integral part of this is the DGA, into which the difference between forecast and actual gas prices accrues. When the DGA balance reaches a pre-set threshold, the utility is required to apply to the AEUB either to recover or pay out the balance of the DGA. Consequently, the AEUB expected the initial focus of the collaborative process to be the identification of these costs and agreement on the amount and timing of the transfer to the GCRR. It considered that the issues of unbundling of storage, other distribution services, and frequency of GCRR changes would likely be the secondary focus of the process.

A collaborative process was undertaken, as directed by the AEUB. However, the collaborative process received mixed reviews from stakeholders, and ultimately the process was suspended in 2000. In the spring of 2001, the AEUB called two generic hearings. The first was to consider the GCRR methodology, including the manner in which the GCRR should be adjusted, the frequency of adjustment, and whether gas utilities should be allowed to or directed to engage in hedging activities.

The second generic hearing called by the AEUB was a generic hearing to consider all aspects of gas utility unbundling. One of the primary concerns of a number of interested parties is that a significant amount of costs related to the supply and management of gas are included in gas utilities' distribution rates, rather than the gas cost recovery rates. At the gas utility unbundling hearing, the AEUB heard a considerable amount of testimony from various parties regarding the process by which gas utility rates should be unbundled and how and when this should be accomplished. It is anticipated that the decisions in these two hearings will set the stage for the move to a fully competitive retail gas market for core customers in Alberta.

During the course of these hearings ATCO Gas announced its intention to remove its company-owned storage from regulation and its intention to exit the merchant function and divest itself of all retail activities. Previously, ATCO Gas North (a division of ATCO Gas and Pipelines Ltd.) applied to the AEUB to sell certain of its production assets. The application was denied with respect to a significant portion of the assets ATCO Gas North had applied to sell. ${ }^{40}$ ATCO Gas stated that it wished to become a "pipes only" company and that it was taking steps to attract a "world-class retailer" to the province, to whom it wished to sell its retail operations. 


\section{LegiSLATIVE DEVELOPMENTS}

The most significant developments this year were the major amendments to the Alberta Oil and Gas Conservation Act. ${ }^{41}$ A bill before the Saskatchewan legislature is poised to make a number of similar amendments to that province's Oil and Gas Conservation Act. $^{42}$ Amendments to the NEB's Cost Recovery Regulations ${ }^{43}$ brought commodity pipelines within the regulations, and the Alberta legislature passed a new act designed to protect Alberta consumers from high natural gas prices. Nova Scotia introduced a comprehensive scheme for the regulation of onshore drilling.

\section{A. FEDERAL \\ 1. CANADIAN ENVIRONMENTAL PROTECTION ACT, $1999^{44}$}

On September 1, 2000, ss. 234 to 241 of the Canadian Environmental Protection Act, $1999,{ }^{45}$ came into force. These provisions deal with environmental protection compliance orders.

\section{NATIONAL ENERGY BOARD ACT, ${ }^{46}$ NATIONAL ENERGY BOARD COST RECOVERY REGULATIONS ${ }^{47}$}

Under s. 24.1 of the National Energy Board Act, the NEB has the power to make regulations for the purpose of recovering costs attributable to its legislated responsibilities. The former version of the Cost Recovery Regulations made oil and gas pipelines and electricity exporters subject to cost recovery. Under the Canada Transportation Act, $1996,{ }^{48}$ jurisdiction over commodity pipelines was transferred from the National Transportation Agency (as it then was) to the NEB.

A commodity pipeline is one that carries a commodity other than oil or gas. The NEB has regulated commodity pipelines since 1996, but these pipelines have not paid any portion of the operating costs of the NEB. The purpose of the amendments ${ }^{49}$ to the Cost Recovery Regulations was to integrate commodity pipelines into the NEB cost recovery methodology.

Small and intermediate commodity pipelines are treated under the amended regulations in the same manner as small or intermediate oil and gas pipelines. Large commodity pipelines are required to pay a flat fee to the Crown. This differs from the cost recovery methodology in relation to large oil or gas pipelines. The rationale for this differentiation

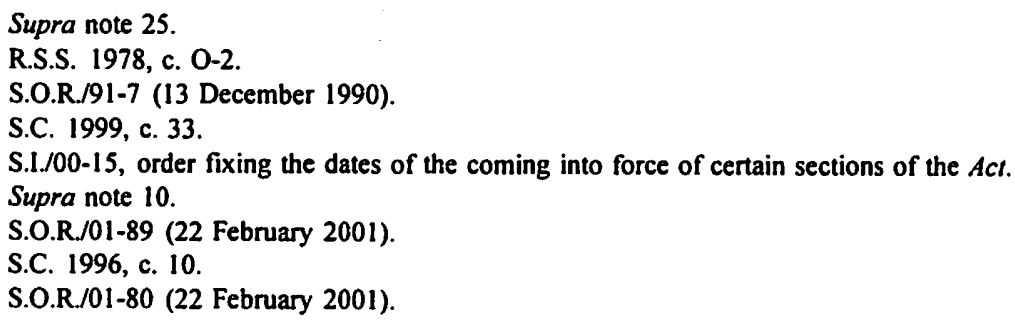


is the fact that there are currently no large commodity pipelines in Canada. If one were constructed and the cost recovery mechanism for large oil and gas pipelines were used, the first large commodity pipeline would bear a disproportionately high proportion of the total costs attributable to the regulation of commodity pipelines.

The amended regulation also sets out a levy assessed as two-tenths of one percent of the estimated cost of the approved facilities. This levy must be paid by any new pipeline. This "greenfield pipeline" levy is intended to reflect the fact that such pipelines claim an inordinately large amount of the resources of the NEB.

Finally, the amendments establish a new cost recovery cap on the liability of pipeline companies to pay cost recovery charges. The amendments establish a rule that no pipeline company will be liable to pay that portion of a cost recovery charge which exceeds 2 percent of the cost of service of the pipeline company. This is intended to ensure that short, large diameter pipelines do not bear an inequitable share of the NEB's costs, since costs are allocated to large oil and gas pipelines on the basis of volumes transported.

\section{NATTONAL ENERGY BOARD ACT, NATIONAL ENERGY BOARD RULES OF PRACTICE AND PROCEDURE, $1995^{50}$}

A number of amendments were made to the Rules of Practice and Procedure ${ }^{51}$ at the end of December. The primary purpose of these amendments is to reflect the NEB's experience with applications for a right of entry order under s. 104 of the National Energy Board Act. ${ }^{52}$ This section sets out the manner by which a pipeline company can obtain a legal interest in property against the wishes of a landowner. The primary problem the amendments are intended to address is a conflict between the National Energy Board Act and the Rules of Practice and Procedure concerning the timing of the filing of a right of entry application.

According to the $A c t$, applications must be submitted to the NEB between thirty and sixty days after notice of the application is served upon a landowner. However, the former rules required a pipeline company to submit its application to the NEB forthwith after service of the notice upon a landowner. Additionally, the former rules did not require an applicant to serve an application for a right of entry order upon a landowner. The NEB appears to have been concerned that if a landowner did not receive a copy of all of the materials submitted by a pipeline company to the NEB, this might offend the principles of natural justice and procedural faimess.

Other problems the amendments to the Rules of Practice and Procedure were intended to address are the following: 
- Under the unamended rules, a pipeline company was only obliged to provide the NEB with proof that a notice was served on the relevant landowner, rather than proof that the complete application was served.

- There were no time limits for the filing of objections by the landowner to the application for a right of entry order.

- There were no time limits for the filing of a reply by the pipeline company to landowner objections.

- A landowner was required to send objections to the company by registered mail, which the NEB apparently believed could operate as a potential barrier to participation in the NEB's process.

The amendments provide that pipeline companies must file an application for a right of entry order between thirty and sixty days following the service by the company of a notice on the landowner. ${ }^{53} \mathrm{~A}$ pipeline company is now required to serve on the landowner all of the material associated with the application, along with the right of entry application. ${ }^{54}$ Landowners are now required to file any objection to an application for a right of entry order with the NEB no later than ten days after the application is served on the landowner by the pipeline company. ${ }^{\text {ss }} \mathrm{A}$ pipeline company that receives an objection from a landowner must file a reply to the objection (or a statement that it does not wish to respond to the objection) within seven days of the date the objection is served on the company. ${ }^{56}$ The requirement that a landowner's objection be served by registered mail has been removed.

Section 8(8) of the Rules of Practice and Procedure ${ }^{57}$ adopts, generally, the rules of the Federal Court of Canada with respect to personal service of documents. Recent amendments to the Federal Court Rules have caused the NEB to review s. 8(8). This section has been amended to take into account changes made to the Federal Court Rules and to clarify the manner in which the provincial Crown is to be served ${ }^{38} \mathrm{~A}$ similar amendment was also made to the NEB substituted service regulations. ${ }^{59}$

lbid., ss. 55(2), 55(3).

Ibid., s. 56(1).

Ibid., s. 56(3).

Supra note 50.

Regulation Amending the National Energy Board Rules of Practice and Procedure, 1995, S.O.R./00361 (22 September 2000). 


\section{B. BRITISH COLUMBiA}

1. PETROLEUM AND NATURAL GAS ACT, ${ }^{60}$

PETROLEUM AND NATURAL GAS ROYALTY AND

FREEHOLD PRODUCTION TAX REGULATION ${ }^{61}$

The Petroleum and Natural Gas Royalty and Freehold Production Tax Regulation ${ }^{62}$ was substantially amended in March 2001.

2. OIL AND GAS COMMISSION ACT, ${ }^{63}$

RECONSIDERATION BY ALTERNATIVE DISPUTE RESOLUTION REGULATION ${ }^{64}$

This regulation sets out the process by which decisions of the Oil and Gas Commission may be reconsidered by alternative dispute resolution.

\section{AlBERTA}

1. OIL AND GAS CONSERVATION ACT ${ }^{65}$

The Oil and Gas Conservation Act was significantly amended by the Energy Statutes Amendment Act, 2000. ${ }^{66}$ These amendments have, among other things, significantly broadened the AEUB's powers to deal with the abandonment of wells and facilities. Additionally, the abandonment fund has been replaced by the orphan fund, which is dedicated to a much broader range of purposes than the former abandonment fund. The amendments also broaden the range of facilities regulated by the AEUB.

A number of new definitions have been added to the Oil and Gas Conservation Act, including definitions of abandonment ${ }^{67}$ and abandonment costs ${ }^{68}$ The Energy Statutes Amendment Act, 2000 also added to the Oil and Gas Conservation Act a definition of "facility," Part 11.1 (which deals with the orphan fund). The definition of "facility" is very broad, extending to buildings, structures, and equipment that is connected to or associated with the recovery, development, handling, processing, treatment, or disposal of hydrocarbonbased resources or any associated substances of wastes.

R.S.B.C. 1996, c. 361 .

B.C. Reg. $495 / 92$.

B.C. Reg. 50/01.

S.B.C. 1998 , c. 39 .

B.C. Reg. $45 / 01$.

Supra note 25.

S.A. 2000, c. 12. The Energy Statutes Amendment Act, 2000 was given Royal Assent on May 30. 2000 , and came into force June $30,2000$.

Supra note $25 \mathrm{~s}$. 1(1)(a).

lbid., s. I(1)(a.01).

Ibid., s. 1(1)(i.2). 
The definition of "facility" includes, for example, a battery, a processing plant, a gas plant, an oilfield waste management facility, a central processing facility, a compressor, a dehydrator, a separator, a treater, a custom treating plant, a produced water injection plant, a produced water disposal plant and a miscible flood injection plant. The definition of "facility" does not include a well, a pipeline, a mine site or processing plant as defined in the Oilsands Conservation Regulation ${ }^{70}$ or the Coal Conservation Act. ${ }^{71}$

Other amendments to the definitions in the Oil and Gas Conservation Act include a definition of "operator,"72 which is defined to mean a person who has control of or undertakes the day-to-day operations and activities at a well or facility; or who keeps and submits production records for a well or facility to the AEUB, whether or not that person is also the licensee or approval holder in respect of the well or facility. Many of the provisions in the Oil and Gas Conservation Act that formerly referred only to wells have now been amended to refer to both wells and facilities. Other new definitions include: reclamation; ${ }^{73}$ reclamation costs; ${ }^{74}$ suspension; ${ }^{75}$ and suspension costs. ${ }^{76}$

Section 10 of the Oil and Gas Conservation Act has been amended to add a provision requiring licensees and approval holders to provide to the AEUB deposits or other forms of security to guarantee the proper and safe suspension, abandonment, and reclamation of wells and facilities. ${ }^{77}$ This is a transitional provision related to the implementation of the AEUB's new retrospective facility licensing program. ${ }^{78}$ The amended Oil and Gas Conservation Act also now contains provisions requiring all applicants for licences or approvals to hold an identification code issued by the AEUB. ${ }^{79}$ An amendment to s. 19 allows the AEUB to cancel a licence for a well if drilling has not commenced within six months after the licence was granted and to cancel a licence or approval for a facility if construction has not commenced within one year after the licence or approval was granted. $^{80}$

Among the most significant changes to the Oil and Gas Conservation Act are the amended provisions dealing with the power of the AEUB to direct and carry out suspensions and abandonments of wells and facilities. The AEUB has the power to direct the suspension or abandonment of a well or facility by a working interest participant other than the licensee or approval holder. ${ }^{81}$ A new provision also stipulates that abandonment of a well or facility does not relieve the licensee, approval holder or working interest

Alta. Reg. 76/88.

R.S.A. 1980 , c. C-14.

Supra note 25 , s. $1(1)(0.2)$.

lbid., s. $1(1)($ (s.2).

lbid., s. I(I)(s.3).

lbid., s. $1(1)(\mathrm{t} .01)$.

Ibid., s. 1(1)(t.02).

Ibid., s. 10(a.2).

Ibid., ss. 11.2, 11.3. The retrospective facility licensing program is outlined in AEUB Guide 68:

Retrospective Facility Licensing (October 2000) and Interim Directive (24 October 2000), ID 200010.

Ibid., ss. 15.1, 15.2 .

Ibid., ss. 19(b), 19(c).

Ibid., s. 20.2(2). 
participant from responsibility for the control or further abandonment of the well or facility, or from the responsibility for the costs of doing that work. ${ }^{82}$

One of the new amendments to the Oil and Gas Conservation Act gives the AEUB the power to deem certain parties to be working interest participants. This amendment gives the AEUB a broad power. For example, where:

- a transaction occurs that results in a person no longer being a working interest participant in a well or facility;

- the successor working interest party is a person other than the licensee of the well or facility; and

- the successor working interest participant fails to pay its proportionate share of the suspension, abandonment or reclamation costs,

the AEUB has the power to deem the original working interest participant to continue to be a working interest participant for certain purposes, including responsibility for suspending or abandoning a well or facility and in respect of the costs of doing that work.

However, there are some conditions on the AEUB's power to deem a former working interest participant to be a continuing working interest participant. For example, this may be done in the case of a well, if a transaction under which the working interest participant ceased to be a working interest participant occurred after the well ceased to meet the economic limit test set out in the regulations; or in the case of a facility, the transaction occurred after the facility ceased operation or after the facility has a throughput that is less than the rate prescribed in the regulations as sufficient to warrant deeming the facility to be active. ${ }^{83}$

According to the new s. 20.7, where a responsibility, obligation or liability is imposed by the $A c t$ or regulations on a licensee, approval holder or working interest participant in respect of the operation, suspension or abandonment of a well or facility, or in respect of any matter arising out of the operation, suspension or abandonment of a well or facility, the responsibility also extends to associated equipment and non-licensed facilities that are located on the site or used in conjunction with the operation, suspension or abandonment of the well or facility, unless such equipment or facilities are excepted from the application of this provision by the regulations.

Another significant change to the Oil and Gas Conservation Act is the overhaul of Part 11.1. This Part formerly dealt with the abandonment fund levy. The abandonment fund has now been replaced by an orphan fund, the application of which had been significantly broadened. Part 11.1 contains a number of definitions, including a definition of "facility." 84 The Part 11.1 definition of "facility" is the same as the general definition 
set out in section 1, except that it includes a pipeline as defined in the Pipeline $\mathrm{Act}^{85}$ and does not include:

- a processing plant or processing plant site as defined in the Oilsands Conservation Regulation; ${ }^{86}$

- a gas processing plant that has sulphur recovery and sulphur storage facilities;

- an oilfield waste management facility;

- a processing plant designated by the AEUB as a straddle plant;

- a refinery as defined in the Pipeline Act;

- an oil transmission pipeline and associated storage, pumping and measurement facility;

- a gas transmission pipeline and associated compression and measurement facility; and

- $\quad$ any facility listed in the regulations as specifically exempted from Part 11.1.

One of the most significant differences between the abandonment fund and the orphan fund is that the orphan fund is specifically dedicated to pay for the suspension costs, abandonment costs, and related reclamation costs in respect, not only of wells, but also of facilities, facility sites and well sites. ${ }^{87}$ The AEUB now expressly has the power to designate wells, facilities, facility sites, and well sites to be orphans for the purposes of Part 11.1. ${ }^{88}$ The AEUB may also deem a working interest participant to be a "defaulting working interest participant" where the working interest participant has an obligation to contribute toward suspension costs, abandonment costs or related reclamation costs, has not contributed to those costs as required, and in the opinion of the AEUB, does not exist, cannot be located, or does not have the financial means to contribute to those costs as required by the Oil and Gas Conservation Act. $^{89}$

Where the AEUB makes a payment from the orphan fund to a person in respect of a defaulting working interest participant's share of suspension, abandonment or reclamation costs, this does not release the defaulting working interest participant from any liability in respect of those costs. Furthermore, if a person who receives the payment later recovers all or part of the costs from a working interest participant, that person must pay to the AEUB an amount equal to the amount recovered, less the reasonable costs of recovery as

\author{
R.S.A. 1980 , c. P-8. \\ Supra note 70. \\ Supra note 25, s. 59(1). \\ Jbid., s. 59(2)(a). \\ Ibid., s. 59(2)(v).
}


determined by the AEUB. ${ }^{90}$ The manner in which the orphan fund levy is determined and collected has not changed significantly.

Section 92 of the Oil and Gas Conservation Act, which gives the AEUB the power to enter onto a site or any structures and do whatever the AEUB considers necessary because of a failure to comply with an order, direction or requirement respecting the control, completion or operation of a well, has been broadened to include the operation of any facility. ${ }^{91}$

The AEUB still has the power to determine the costs of or incidental to work carried out in this regard and to allocate those costs among the licensees, approval holders and working interest participants as the AEUB considers appropriate. However, this has been supplemented by a new provision that allows the certified copy of the order of the AEUB allocating these costs to be filed in the office of the Clerk of the Court of Queen's Bench and be entered as a judgment of the court. This allows the AEUB's order to be enforced according to the procedure for enforcement of judgments of the Court of Queen's Bench. $^{92}$

Section 93.1 has been changed to expressly give the AEUB a lien in respect of any debt to the AEUB for costs, levies, fees, penalties or other amounts. This is a clarification, which expressly gives the AEUB a lien, where a lien arguably arose only by implication in the repealed s. 92.1. The garnishment power under this section has also been strengthened by the addition of a provision that stipulates that a person who fails to comply with a notice of garnishment or makes payment to a debtor in contravention of the notice of garnishment is indebted to the AEUB for an amount equal to the amount that person was required to pay pursuant to the notice of garnishment or the amount of the payment made to the debtor, whichever is less. ${ }^{93}$

Section 94, which dealt with the process by which the AEUB had the power to deal with an escape of oil, has been broadened to include crude bitumen, water or any other substance. ${ }^{94}$

The Oil and Gas Conservation Act has also been amended to give the AEUB certain powers with respect to directors, officers, agents or other persons who, in the AEUB's opinion, were directly or indirectly in control of the licensee, approval holder or working interest participant. If a licensee, approval holder or working interest participant contravenes or fails to comply with an order of the AEUB or has an outstanding debt to the AEUB, and if the AEUB considers it in the public interest to do so, the AEUB now has the power to make a declaration setting out the nature of the contravention and to name one or more directors, officers, agents or other persons who were directly or indirectly in control of the licensee, approval holder or working interest participant. 
Before the AEUB makes such a declaration, it must first give written notice of its intention to do so to the affected directors, officers, agents or other persons and give them at least ten days to show cause as to why the declaration should not be made. Where the AEUB makes such a declaration, it may, subject to any terms and conditions it considers appropriate:

- $\quad$ suspend any operations of a licensee or approval holder, including a licensee under the Pipeline Act;

- refuse to consider an application for an identification code, licence or approval from an applicant under the Oil and Gas Conservation Act or the Pipeline Act;

- refuse to consider an application to transfer a licence or approval under the Oil and Gas Conservation Act or a licence under the Pipeline Act;

- require the submission of abandonment and reclamation deposits prior to the granting of any licence, approval or transfer under the Oil and Gas Conservation $A c t$; and

- require the submission of abandonment and reclamation deposits for any wells or facilities of any licensee or approval holder. ${ }^{95}$

\section{PIPELINE $A C T$}

The Energy Statutes Amendment $A c t^{96}$ also made a number of amendments to the Pipeline Act. ${ }^{97}$ Among these amendments is the deletion of any reference to a permit. A permit was formerly required to construct a pipeline, while a licence was required to operate a pipeline. According to the new amendments, a licence is now required to construct and operate a pipeline.$^{98}$ As well, a number of provisions have been added to the Pipeline Act dealing with the discontinuation and abandonment of pipelines. These provisions mirror the provisions in the newly-amended Oil and Gas Conservation Act. ${ }^{99}$

\section{NATURAL GaS PRICE PROTECTION ACT ${ }^{300}$}

This $A c t$, introduced shortly after the provincial election, sets out the government's scheme to protect Alberta consumers of natural gas from high prices. Where the Minister of Energy is of the opinion that the "Alberta price" is or is likely to be greater than the amount prescribed in the regulations, the Cabinet may authorize a rebate to eligible consumers in Alberta under the regulations. ${ }^{101}$ This $A c t$ also allows the Minister of Energy to publish a "national residential gas reference price" based on factors the Minister

Ibid., s. 95.1. This section was proclaimed in force June 30, 2000.

Supra note 66.

Supra note 85.

See, for example, s. 1(1)(h) (ibid.).

See, for example, supra note 25 , ss. 28.1, 28.2, 28.3, 28.5, 28.6 and 50.1.

S.A. 2001, c. N-35.

Ibid., s. 2. 
considers appropriate. ${ }^{102}$ The Natural Gas Price Protection Act and the Natural Gas Price Protection Regulation came into force on July 1, 2001. ${ }^{103}$ This Act is an example of legislation where the skeleton is found in the $A c t$, while the meat is found in the Regulation.

\section{MINES AND MINERALS ACT, ${ }^{104}$ OILSANDS TENURE REGULATION ${ }^{105}$}

The Oilsands Regulation ${ }^{106}$ has been repealed and replaced by the Oilsands Tenure Regulation. The Oilsands Tenure Regulation is subject to a sunset clause with a date of December 1, 2004. The Oilsands Tenure Regulation deals with, among other things, oilsands agreements ${ }^{107}$ and continued leases. ${ }^{108}$

\section{PUBLIC LANDS ACT, ${ }^{109}$ GOVERNMENT FEES AND CHARGES REVIEW ACT, ${ }^{110}$ DISPOSITIONS AND FEES REGULATION ${ }^{\prime \prime \prime}$}

The Public Lands Pipe Line Regulations ${ }^{112}$ have been repealed and replaced by Part 8 of the Dispositions and Fees Regulation, which sets out the manner in which a pipeline operator may obtain public land required for a pipeline and a pipeline right-of-way.

\section{SASKaTCHEWAN}

\section{AN ACT TO AMEND THE OIL AND GAS CONSERVATION ACT ${ }^{13}$}

This bill is currently before the legislature in Saskatchewan and, if passed, will make extensive changes to the Oil and Gas Conservation Act, ${ }^{114}$ many of which are similar to the recent amendments to the Alberta Oil and Gas Conservation Act. Among the amendments proposed by this bill is the power to require security for the purpose of ensuring suspension, abandonment, restoration, remediation or reclamation obligations. ${ }^{115}$ Other proposed changes include the addition of Part III.2, which continues the oil and gas environmental fund as the oil and gas orphan fund.

lbid., s. 5.

The Act received Royal Assent on May 31, 2001. The Regulation, Alta. Reg. 157/2001, expires on June 30, 2003.

R.S.A. 1980, c. M-15.

Alta. Reg. 50/00.

Alta. Reg. 228/91.

Supra note 105, Part 1.

Ibid., Part 2.

R.S.A. 1980 , c. P-30.

S.A. 1999, c. G-6.5.

Alta. Reg. 54/00.

Alta. Reg. 246/58.

This Bill was passed by the Saskatchewan Legislature and is now the Oil and Gas Conservation Amendment Act, 2001, S.S. 2001, c. 26.

Supra note 42.

Ibid., s. 15. 


\title{
2. THE PIPELINES ACT, $1998^{116}$
}

Although this $A c t$ was assented to June 11, 1998, it was not proclaimed in force until April 1, 2000. With the proclamation of this Act, the Pipe Lines $A c t^{17}$ was repealed. The Pipelines Act, 1998, sets out comprehensive provisions dealing with the regulation and operation of pipelines, including the requirement of licences, provisions dealing with the taking and use of land, and the operation of pipelines.

\section{E. Nova Scotia}

1. GAS DISTRIBUTION ACT, ${ }^{118}$

GAS DISTRIBUTION REGULATIONS (NOVA SCOTIA) ${ }^{19}$

The definition of "delivery of gas for ultimate consumption" has been amended. ${ }^{120}$

\section{PETROLEUM RESOURCES ACT ${ }^{21}$ \\ ONSHORE PETROLEUM AND DRILLING REGULATIONS ${ }^{122}$}

The Onshore Petroleum Drilling Regulations set out a fairly comprehensive scheme by which onshore drilling is to be conducted in Nova Scotia. These regulations set out the form of applications for obtaining an authorization to drill, suspend, complete or abandon a well. The regulations also set out a number of provisions with respect to abandoning wells, including a provision that creates continuing responsibility of operators for abandoned wells, if the abandonment of the well is found not be in accordance with the regulations or an authorization. ${ }^{23}$

The new regulations cover all onshore oil and gas drilling activities and provide that occupational health and safety and protection of the environment are the responsibility of the Department of Environment and Labour.

\author{
S.S. 1998, c. P-12.1. \\ R.S.S. 1978 , c. P-12. \\ S.N.S. 1997 , c. 4 . \\ O.C. $576 / 98$. \\ N.S. Reg. $183 / 00$. \\ R.S.N.S. 1989, c. 342. \\ N.S. Reg. 29/01 (30 March 2001). \\ Ibid., ss. 31-34.
}




\section{F. Prince Edward ISLAND}

1. OIL AND NATURAL GAS ACT, ${ }^{124}$

PERMTT, LEASE AND SURVEY SYSTEM REGULATIONS ${ }^{125}$

Prince Edward Island established the Permit, Lease and Survey System Regulations, which, among other things, sets out the process for a call for bids for an oil and natural gas permit and the bidding procedure. ${ }^{126}$ The regulations also set out the terms of onshore and offshore permits, ${ }^{127}$ and set limits for the proximity of onshore and offshore wells to the boundaries of onshore or offshore permits. ${ }^{128}$

\section{Policies, Directives ANd Guidelines}

The Newfoundland and Nova Scotia offshore boards developed a new set of guidelines dealing with financial responsibility requirements for offshore work, and the Canada-Nova Scotia Offshore Petroleum Board has released draft guidelines regarding offshore drilling programs. The AEUB released a number of significant new policies and directives, supplementing the new amendments to the Alberta Oil and Gas Conservation Act, implementing the expanded orphan program and introducing a retrospective facility licensing program and significant new licence transfer requirements.

\section{A. Canada-Newfoundland OfFShore Petroleum Board ("CNOPB") ANd Canada-Nova SCOTIa OfFShORE PETROleum BoARd ("CNSOPB")}

1. CNOPB, CNSOPB GUIDELINES RESPECTING FINANCIAL RESPONSIBILITY, REQUIREMENTS FOR WORK OR ACTIVITY IN THE NEWFOUNDLAND AND NOVA SCOTIA OFFSHORE AREAS ${ }^{129}$

Under the federal and provincial statutes arising from the Atlantic Accord ${ }^{130}$ and the Canada-Nova Scotia Offshore Resources Accord, ${ }^{131}$ any person wishing to conduct any work or activity in Newfoundland or Nova Scotia offshore areas must provide proof of financial responsibility in a form and amount satisfactory to the CNOPB or the CNSOPB.

The purpose of the new guidelines is to provide guidance to operators with respect to providing proof of financial responsibility regarding any authorization being sought for work or activity related to drilling, development, decommissioning or other operations in the Newfoundland or Nova Scotia offshore areas. The guidelines cover the following areas:

R.S.P.E.1. 1988, c. O-5.

P.E.I. Reg. EC689/00.

Ibid., ss. 2-5.

Ibid., s. 8.

lbid., ss. 13, 14.

December 2000.

Canada-Newfoundland Atlantic Accord Implementation Act, S.C. 1987, c. 3.

Canada-Nova Scotia Offshore Petroleum Resources Accord Implementation Act, S.C. 1988, c. 28. 
- the approval process;

- objective of financial responsibility requirements;

- identification and overview of relevant legislative provisions; and

- required evidence of financial responsibility.

\section{CNSOPB DRAFT GUIDELINES RESPECTING DRILLING} PROGRAMS IN THE NOVA SCOTIA OFFSHORE AREA ${ }^{132}$

The CNSOPB is the body responsible for the administration and regulations relating to exploration and production of petroleum in the Nova Scotia offshore area. These guidelines are intended to assist operators planning to conduct a drilling program within this area and provide information and explanation with respect to the requirements set out in the Canada-Nova Scotia Offshore Petroleum Resources Accord Implementation Act and the Canada-Nova Scotia Offshore Petroleum Resources Accord.

The guidelines discuss in detail the requirement to obtain a drilling program authorization ("DPA") ${ }^{133}$ and the approval to drill a well ("ADW"). ${ }^{134}$ The draft guidelines also cover the following areas:

- exploration, significant discovery and production licence;

- operating licence; and

- required records and reports.

\section{B. Alberta ENERgy AND Utilities BoARd}

\section{Retrospective FaCILITY Licensing Program}

A number of recent regulatory changes are associated with the development by the AEUB of the Expanded Orphan Program (which replaces the Abandonment Program and is implemented through the amended Part 11.1 of the Oil and Gas Conservation Act ${ }^{135}$ ). Perhaps the most ambitious aspect of the new program is the Retrospective Facility Licensing Program. ${ }^{136}$ The Retrospective Facility Licensing Program introduces the requirement for licensing of certain existing upstream oil, bitumen and gas production, and injection facilities which have previously not required licensing. The Retrospective Facility

January 2001 (Revision 1.0 01/01).

The DPA authorizes an operator to conduct a drilling program, including all operations and activities ancillary to that program.

The ADW permits an operator to drill a particular well using the procedures described in the application and well prognosis.

Supra note 25.

See ID 2000-10 and Guide 68, supra note 78. 
Licensing Program applies to facilities regardless of their operational status: approved but not constructed, operating, inactive, abandoned, or reclaimed (certified or exempt). ${ }^{137}$

One of the keys to the Retrospective Facility Licensing Program is an expanded definition of "facilities," included in recent amendments to the Oil and Gas Conservation Act. Under the new program, a number of types of facilities that did not previously have to be licensed now require licensing. ${ }^{138}$

\section{HOW DOES THE RETROSPECTIVE LICENSING PROGRAM WORK?}

The AEUB provides each operator currently within the AEUB's jurisdiction with a list of facilities which, according to the AEUB's records, are that operator's responsibility. Operators may also access the list of its facilities through the AEUB web site using its operator/company identification code and a password provided by the AEUB.

Upon completion of the Retrospective Facility Licensing Program, the AEUB will send each licensee a list of all facilities licensed in its name, as well as an individual licence for each facility. During the Retrospective Facility Licensing Program, the AEUB will accept and process licence transfer applications in accordance with the requirements set out in Guide 68. After the Retrospective Facility Licensing Program, facility transfer applications will not be approved unless both the proposed transferor and transferee have fulfilled the requirements of the program.

In any transaction involving the transfer of resource properties that are subject to the Retrospective Facility Licensing Program, there is the potential for increased exposure to abandonment and reclamation liability, as facilities formerly not regulated by the AEUB will be regulated by the AEUB as a result of the new program.

\section{LICENCE TRANSFER REQUIREMENTS}

The AEUB has also introduced new requirements and a new process to obtain approval of well, facility and pipeline licence transfers. ${ }^{139}$ The AEUB now assesses the risk of unfunded abandonment and reclamation liabilities using two new processes: the Transfer Liability Rating ("TLR") and the Licensee Liability Rating ("LLR"). These are intended to replace the well screening ratio ("WSR") formerly used in assessing licence transfer applications.

However, in April 2001 the AEUB introduced a revised TLR process. ${ }^{140}$ The revised process has been adopted on an interim basis and is to expire on December 31, 2001. The

\footnotetext{
137 However, no licences will be issued for reclaimed sites.

138 See supra note 84 and accompanying text.

139 See Interim Directive (24 October 2000), ID 2000-11; General Bulletin GB 2000-28 and Informational Letter (24 October 2000), IL 2000-4 (A.E.U.B.). out in the amendment supersedes those sections of ID 2001-11 that refer to the TLR assessment and TLR security deposit processes.
} 
revised TLR process was developed by the AEUB in consultation with CAPP, SEPAC and took into account comments of non-industry association licensees.

Under the revised TLR process, the AEUB evaluates the transferor based on the ratio of active to inactive wells (WSR) remaining in the transferor's inventory as if the transfer were approved. Facilities are not considered in this evaluation. If the WSR is greater than 1.0 a security deposit is not required. If the WSR is less than 1.0 a security deposit is required and is calculated according to a formula.

A TLR assessment of a licence transfer application will only be conducted if the transferee fails the WSR evaluation described above. The TLR assessment of a licence transfer application is based on the ratio of active wells to inactive wells and the "well equivalent"141 of any facility with a throughput of less than 20 percent of design capacity that is included in the application. A facility operating at or above 20 percent of its design capacity is considered to be neutral and is not included in the evaluation. The TLR of a licence transfer application is determined using a formula that results in a ratio. If the ratio is greater than 1.0 the transferee is not required to post a deposit. A ratio of less than 1.0 will result in a deposit being required from the transferee. The deposit is calculated according to a formula.

Any licence transfer application that was assessed in accordance with the original TLR process has been or will be reassessed using the revised process.

The AEUB has indicated it intends to make monthly LLR determinations and will use these ratings for corporate level liability risk assessments. The stated purpose of the new processes is to minimize the risk of unfunded abandonment and reclamation liabilities of well and facility licensees.

The LLR compares a licensee's total inventory of wells producing at or above two times the calculated economic limit ("EL") 142 of the pool in which they are located ("above 2EL wells") against its inventory of wells not producing above 2EL ("below 2EL wells"), one-half the number of abandoned and unreclaimed wells, and facilities operating at a rate of less than 20 percent of their design capacity. LLR is then calculated using a formula established by the AEUB. Certain enumerated facilities are not considered in the LLR calculation.

Once the AEUB has determined a licensee's LLR, it will place the licensee into one of three risk status ranges: low, medium or high. A licensee with an LLR outside of the low-risk range is considered to be at risk of being unable to fund its abandonment and reclamation responsibilities and will be required to take certain actions. The threshold values for low-, medium- and high-risk licensees will be established by the AEUB after detailed facility information has been gathered through the retrospective licensing program.

142 Pool EL information is available on the AEUB's web site, supra note 2. See General Bulletin GB 2001-2. 
Low-risk licensees will not be required to post an LLR security deposit. Medium-risk licensees will have three years to improve its LLR to low-risk. If they do not do so, they will be required to post a security deposit for the number of well equivalents that would equate to the licensee attaining a low-risk rating. High-risk licensees will be immediately required to post a security deposit for the number of well equivalents that would equate to the licensee attaining a low-risk rating.

The new licence transfer process requires the submission of a licence transfer application form and supporting schedules, rather than assignment documents and statutory declarations, as was previously required. Additionally, the AEUB encourages licensees to submit complete applications containing all licences involved in a property transfer, rather than submitting a number of separate applications for the same transaction.

Any licence transfer application which contains wells or facilities is subject to a TLR assessment. Once the LLR process has been implemented, the AEUB will assess the LLR of both the transferor and the transferee to determine the impact of the transfer on both licensees' liability ratings. If the post-transfer rating of either the transferor or the transferee falls below the low-risk level, additional LLR security deposits may be required. The TLR is calculated using a formula established by the AEUB.

Initially, the TLR pass/fail criterion was set at 0.8 . A licence transfer application failing to meet this TLR must post a security deposit with the AEUB. The security deposit must address the abandonment and reclamation liabilities of all below $2 \mathrm{EL}$ wells, below 20 percent facilities, and any problem sites within the application before the transfer will be approved.

Security deposits must be in the form of cash or letters of credit which meet certain requirements established by the AEUB. ${ }^{143}$ The AEUB's web site has a security deposit calculation program. By way of example, the LLR security deposit requirement is $\$ 50,000$ for each well equivalent.

A security deposit will only be refunded if the well, facility or site:

- meets its economic test (e.g., 2EL well or above);

- is transferred with AEUB approval to another licensee;

- is fully abandoned (only the abandonment portion of the deposit will be refunded); or

- has a reclamation certificate.

Transfer applications during the Retrospective Facility Licensing Program will be subject to evaluation using TLR but not LLR. However, LLR security deposits may be required once the Retrospective Facility Licensing Program is completed. 
A licence for an abandoned well, facility or pipeline cannot be transferred. However, the AEUB will consider an application from a party other than the licensee to re-enter a well, construct a new facility, or reactivate a pipeline through a new application. Licensees retain liability for an abandoned well, facility or pipeline until another licensee assumes that responsibility as a result of relicensing the well, facility or pipeline. Accordingly, in the case of a transaction which contemplates the transfer of a number of wells, some of which are producing and some of which are abandoned, the licences associated with the producing wells can be transferred (subject to the possible requirement of a security deposit), but the licences associated with the abandoned wells cannot be transferred.

However, it appears that, assuming the buyer has also taken on the underlying mineral rights, the buyer can apply to re-enter the well, obtain a new licence and not re-enter the well. In this fashion, the liability associated with the abandoned well is transferred to the buyer. The detailed requirements relating to facility transfer applications are set out in AEUB Guide $69 .{ }^{144}$

Clearly, these recent regulatory changes have the potential to impact transactions involving resource properties licensed by the AEUB. Care should be structured to take the new regulatory requirements into account, as the transfer might result in the transferee having to post substantial security deposits. This would be the case, for example, if the newly acquired wells decreased the transferee's LLR, or where the TLR falls below the required benchmark. As well, transactions which contemplate transferring abandoned wells will involve a new licence application from the transferee, which cannot be made unless the transferee also has title to the underlying mineral estate. This may involve increased regulatory expense.

In a case where a number of resource properties are being acquired, with the intention of holding those properties in a number of subsidiaries, the introduction of the LLR should be taken into account. The mix of resource properties held by a subsidiary as licensee will affect that subsidiary's LLR and whether the subsidiary will have to post a security deposit.

\section{INTERIM DiRECTIVE: LICENCE ELIGIBILITY AND QUALIFICATIONS FOR POTENTIAL LICENSEES AND AGENTS ${ }^{145}$}

All potential licensees are required to apply for and obtain an identification code prior to making any application to acquire an AEUB licence. The policies set out in this Interim Directive were facilitated by changes to the Oil and Gas Conservation Act set out above. AEUB identification codes (which were formerly known as company or operator codes) now incorporate a "licence eligibility attribute" for internal AEUB use. This attribute identifies whether the holder of the code is eligible to acquire licences and the nature and 
extent of licences that may be acquired. Additional information regarding applications for identification codes is set out in the new Guide 67. ${ }^{146}$

5. INTERIM DIRECTIVE: NOTIFICATION REQUIREMENTS FOR THE DISCONTINUATION AND ABANDONMENT OF PIPELINES AND THE ABANDONMENT OF FACILITIES ${ }^{147}$

This interim directive sets out the requirement for licensees to notify the AEUB of the abandonment of a licensed facility. This requirement replaces the former requirement that a licensee obtain AEUB approval for the discontinuation and abandonment of a pipeline with a notification process. The interim directive does not affect the process for suspension and abandonment of wells. This interim directive is intended to support the AEUB's new Expanded Orphan Program.

Pipeline licensees are no longer required to formally apply to the AEUB for approval to discontinue or abandon pipelines. Licensees must submit a licence amendment within ninety days of the completion of the discontinuation or abandonment. ${ }^{148}$

\section{INFORMATIONAL LETTER: APPROPRIATE DISPUTE RESOLUTION \\ (“ADR”) PROGRAM AND GUIDELINES FOR ENERGY INDUSTRY DISPUTES ${ }^{149}$}

This Informational Letter sets out the framework for the AEUB's ADR program, which the AEUB expects to be used to assist in the resolution of disputes concerning the Alberta energy industry. ${ }^{150}$

Among the identified goals of the AEUB ADR program are:

- improved landowner-industry relations;

- better use of the AEUB's and stakeholder's time and other resources;

- more face-to-face discussions between affected landowners and company decision-makers, leading to local solutions to local problems;

- increased resolution of industry-to-industry disputes without a hearing; and

- a more effective and efficient hearing, if one is necessary.

Guide 67: Identification Code and Agent Registration Application Guide for Potential Licensees (September 2000) (A.E.U.B.).

(October 24, 2000), ID 2000-9.

Further details are set out in Schedule 3 of the new Guide 56: Energy Development Application Guide (24 October 2000) (A.E.U.B.).

(8 January 2001), IL 2001-1 (A.E.U.B.).

More details on the framework for the ADR program are set out in the "Report for Implementation of an Appropriate Dispute Resolution System for Alberta's Upstream Petroleum Applications" (1 May 2001). This report is available on the AEUB web site, supra note 2. 
Participation in the ADR program is voluntary. However, the AEUB "strongly encourages" 151 parties to at least attend a preliminary ADR meeting to discuss options and procedures to deal with the dispute. The AEUB has also stated that the use of ADR should not delay the AEUB's decision on the need for or the scheduling of a hearing. The AEUB has established a multi-year stakeholder committee to monitor the ADR program over the initial three-year period.

The AEUB has indicated that its ADR process is applicable both to industry-to-industry disputes as well as public-to-industry disputes. The AEUB expects parties to consider the ADR process to be an extension of the AEUB's expectations for contact, consultation and disclosure.

\section{GUIDE 56: ENERGY DEVELOPMENT APPLICATION GUIDE ${ }^{152}$}

A new Guide 56 was introduced on October 24,2000 . The new guide contains a number of new forms. The portion of the guide dealing with public consultation has been significantly re-worked, and applicants must now use a prescribed AEUB letter and certain prescribed pamphlets in the information package applicants are obliged to provide landowners, local residents, and other parties who may be directly and adversely affected by the application.

According to the new Guide 56, all category E applications (including rate critical and proximity critical facilities and sulphur recovery gas plants) are deemed to be non-routine and are subject to full upfront review. 